\title{
Angiogenesis and Growth Factor Expression in a Model of Transmyocardial Revascularization
}

\author{
Mare P. Pelletier, Department of Cardiothoracic Surgery, MeGill \\ University, Montreal
}

Submitted March 20, 2000

A thesis submitted to the Faculty of Graduate Studies and Research in partial fulnilment of the requirements of the degree of Master's in Experimental Surgery.

No part of this manuscript may be reproduced without prior written consent from the author or McGill University. Marc P. Pelletier, 2000. 
National Library of Canada

Acquisitions and Bibliographic Services

395 Wellington Street Ortawa ON K1A ONA Canada
Bibliotheque nationale du Canada

Acquisitions et services bibliographiques

395, rue Wellington

Ottawa ON KIA ON4 Canada
The author has granted a nonexclusive licence allowing the National Library of Canada to reproduce, loan, distribute or sell copies of this thesis in microform, paper or electronic formats.

The author retains ownership of the copyright in this thesis. Neither the thesis nor substantial extracts from it may be printed or otherwise reproduced without the author's permission.
L'auteur a accordé une licence non exclusive permettant à la

Bibliothèque nationale du Canada de reproduire, prêter, distribuer ou vendre des copies de cette thèse sous la forme de microfiche/film, de reproduction sur papier ou sur format électronique.

L'auteur conserve la propriété du droit d'auteur qui protège cette thèse. Ni la thèse ni des extraits substantiels de celle-ci ne doivent être imprimés ou autrement reproduits sans son autorisation. 


\section{ABSTRACT}

Introduction. The mechanism by which transmyocardial revascularization (TMR) exerts a beneficial effect remains unknown. This thesis hypothesizes that myocardial punctures for TMR cause a myocardial injury, leading to an angiogenic response mediated by a number of growth factors.

Methods. Fifty-three rats underwent ligation of the left coronary artery. Group I $(n=25)$ served as controls, while Group II $(n=28)$ underwent concomitant TMR by creating six transmural channels with a 25-gauge needle in the ischemic zone. Surviving animals in both groups were sacrificed at intervals of $1,2,4$, and 8 weeks ( $n=5$ in each subgroup). Immunohistochemistry in the infarct areas was performed for factor VIII to assess vascular density. Immunohisto-chemistry using specific antibodies was also performed for transforming growth factor- $\beta$ (TGF $\beta$ ), basic-fibroblast growth factor (b-FGF), and vasoendothelial growth factor (VEGF). Growth factor expression was quantitated by comparing areas of staining (in $\mathbf{~ m}^{2}$ ) using computerized morphometric analysis. Results. Mortality was similar in both groups (5/25 vs. 8/28, p=NS). Group II had significantly greater vascular density than Group I (5.65 vs. 4.06 vessels/HPF, $p<0.001$ ), with a peak at 1 week post-operatively ( 9.12 vs. 5.56 vessels/HPF, $p<0.0001)$ in both groups. Overall, both TGFB and bFGF were significantly higher in the TMR group compared to the control group $\left(0.207 \mathrm{~mm}^{2} / \mathrm{mm}^{2}\right.$ vs. $0.141 \mathrm{~mm}^{2} / \mathrm{mm}^{2}, \mathrm{p}<0.05$ and 0.125 $\mathrm{mm}^{2} / \mathrm{mm}^{2}$ vs. $\left.0.099 \mathrm{~mm}^{2} / \mathrm{mm}^{2}, \mathrm{p}<0.05\right)$.

Conclusions. This model of TMR is associated with a significant angiogenic response, which appears to be mediated by the release of cerain angiogenic growth factors such as TGF $\beta$ and bFGF. With the long term patency of laser-created myocardial channels in clinical TMR increasingly in doubt, its mechanism of myocardial revascularization may be similar to that observed in our model. 


\section{ABSTRAIT}

Introduction. Le mécanisme causant un bénéfice dans la procédure de révascularization transmyocardiale (RTM) demeure inconnu. L'hypothese de cette these est que !es crevaisons créé par le RTM causent une blessure au myocarde, et ensuite une reponse angiogenique qui est influencé par certain facteurs de croissance.

Méthodes. Cinquante-trois rats ont subi une ligature de l'artère coronaire gauche. Groupe I $(n=25)$ ont servi comme controles, tandis que Groupe II $(n=28)$ ont aussi subi une RTM en même temps en créant six canaux transmurale dans la zone ischémique avec une aiguille de 25-jauge. Les animaux ayant survécu dans les deux groupes ont êté sacrificié à des intervales de $1,2,4$, et 8 semaines ( $n=5$ dans chaque sous-groupement). Les zones ischémiques ont été analyzé pour la présence de facteur VIII et de densité vasculaire par immunohistochimie. L'himmunohistochimie avec des anticorps spécifiques pour transforming growth factor- $\beta$ (TGF- $\beta$ ), basic-fibroblast growth factor (bFGF), et vasoendothelial growth factor (VEGF) à aussi été utilisé. L'expression des facteurs de croissance à été mesuré par comparaison des endroits taché (en $\mathrm{mm}^{2}$ ) avec une analyze morphométrique informatisée.

Résultats. Mortalité était semblable dans les deux groupes (5/25 vs. 8/28, $\mathrm{p}=\mathrm{NS}$ ). Groupe II avait une densité vasculaire sensiblement plus élevé que Groupe I (5.65 vs. 4.06 vaisseaux/HPF, $p<0.001)$, avec un sommet après 1 semaine post-opératoire (9.12 vs. 5.56 vaisseaux/HPF, $\mathrm{p}<0.0001$ ) dans les deux groupes. En tout, TGFß et bFGF était sensiblement plus élevé dans le groupe de RMT comparé au groupe de controle $\mathbf{0 . 2 0 7}$ $\mathrm{mm}^{2} / \mathrm{mm}^{2}$ vs $0.141 \mathrm{~mm}^{2} / \mathrm{mm}^{2}$, p $<0.05$ et $0.125 \mathrm{~mm}^{2} / \mathrm{mm}^{2}$ vs. $0.099 \mathrm{~mm}^{2} / \mathrm{mm}^{2}, \mathrm{p}<0.05$ ).

Conclusions. Ce modèle de RMT est associé avec une réponse angiogénique importante, qui semble être associé avec la présence de certains facteurs de croissance angiogénique, tel que TGF $\beta$ et bFGF. Alors que des ouvertures permanente dans le myocarde cré par la 
RMT au laser sont en doute, le mécanisme de révascularization myocardiale est possiblement semblable à celui observé dans ce modèle. 


\section{TABLE OF CONTENTS}

$\begin{array}{lll}\text { I. Introduction } & \mathbf{8}\end{array}$

II. Literature Review 10

A. Myocardial revascularization 10

B. Myocardial anatomy and role of sinusoids 12

C. Development of transmyocardial punctures 13

D. Mechanisms and controversies in TMR 16

$\begin{array}{ll}\text { i. Patent channels } & 17\end{array}$

$\begin{array}{ll}\text { ii. Denervation } & 18\end{array}$

iii. Angiogenic growth factors 19

E. Modulation of angiogenesis $\quad 20$

i. Role in wound healing 20

ii. Role in ischemic myocardium 21

III. Rationale for Thesis 23

IV. Study Hypothesis $\quad 24$

V. Study Design $\quad 24$

$\begin{array}{ll}\text { A. Statement of significance } & 25\end{array}$

VI. Material and Methods 26

$\begin{array}{ll}\text { A. Animals } & 26\end{array}$

$\begin{array}{ll}\text { B. Surgery } & 26\end{array}$ 
TABLE OF CONTENTS (Cont.)
C. Harvest
D. Immunohistochemistry
E. Image analysis
F. Statistics

$\begin{array}{lll}\text { VII. Results } & 28\end{array}$
A. Mortality
28
B. Angiogenesis
29
C. TGF- $\beta$
D. bFGF
E. VEGF

VIII. Discussion 31

IX. Future Studies $\quad 36$

$\begin{array}{lll}X \text {. Conclusion } & 37\end{array}$

XI. Legend for Tables and Figures 38

XII. Reference List 52 


\section{ACKNOWLEDGMENTS}

There are many people whose encouragement and support played a major role in the process and outcome of this study. Of most importance was Dr. Ray C.-J. Chiu, a brilliant researcher and physician who has supervised a veritable gold mine of a laboratory in terms of innovation and creativity, including this project. He is all that a supervisor should be: Thoughtful, dedicated, inquisitive, and encouraging. In navigating the fine line between allocating responsibility and providing guidance, he is above all a just and wonderful person.

I want to thank Suj Sivaraman, who devoted many hours of his personal time during a busy medical school schedule in order to help with the heavily time-consuming analysis of immunohistochemistry. His multitude of hours spent at night and on weekends provided essential data for this study.

To Dr. Adel Giaid for his methodological and theoretical input. The technical expertise required for the proper scientific methodology would not have been possible without his help. In a true collaborative effort, meaningful work was achieved.

To Drs. Carlos Li and Anie Philip, a generous thanks in the assessment and critique of this project during its creative and beginning phases. Your insight and constructive criticism helped to assure the scientific validity of this study.

To the division of animal care, a debt of gratitude is owed for helping in the care of all animals, either pre- or post-operatively. To Allana Melanson and Emma Lisi, a huge word of thanks for their ever-present kindness and help with administrative difficulties.

Finally, on a personal note, I wish to thank my family, notably my wife, for her love and support during this period of my life. The multitude of work, combined with the tragedy of my sister's untimely death, made this a difficult period at times. However, with her memory at hand and such loving support, this experience was very rewarding. 


\section{INTRODUCTION}

Myocardial revascularization for ischemic heart disease is a well accepted treatment modality to improve mortality and morbidity. The two major procedures clinically applied for such purposes include coronary artery bypass grafting (CABG) and percutaneous coronary angioplasty (PTCA). Annually, it is estimated that over 250,000 PTCAs are performed annually, with a similar number of CABGs performed. However, a number of patients with ischemic disease will not be candidates for PTCA or CABG because of inadequate coronary anatomy, often termed "diffuse terminal vessel" disease. For these patients, therapy is limited to medical management or ultimately, if appropriate, heart transplantation. Recently, the concept of transmyocardial revascularization (TMR) has resurfaced as an alternative therapy to treat these patients. The aim of TMR has been to allow direct perfusion of ischemic myocardium by ventricular blood. In essence, this procedure consists of creating transmyocardial channels (Figure 1), from the epicardial to the endocardial surface, by using either a hypodermic needle (previously termed myocardial acupuncture) or a laser (carbon dioxide or holmium:yttrium-aluminum-garnet (YAG) lasers). Presently, TMR is being performed in numerous centers across the world with the laser as a tool to "drill" the holes. In both North America and Europe, this procedure is being evaluated in various phase III clinical trials. The prevailing thought is that revascularization is achieved by blood-flow through patency of these newly created channels. However, much discrepancy has arisen regarding the long-term patency of these channels, despite an apparent clinical benefit observed. Altemative mechanisms have been proposed, including the role of angiogenesis as a contributing factor. Indeed, since most observers are now reporting that channel patency plays a minimal role in the benefits observed clinically, an alternative explanation is needed.

Patients with disabling angina are usually treated along an algorithm [1] which first includes the reduction of atherosclerotic-inducing risk factors, such as smoking, 
hypercholesterolemia, hypertension, and hyperglycemia. Pharmacological therapy is often the next step, aimed at improving myocardial oxygen supply (e.g. calcium channel blockers, nitrates), decreasing demand ( $\beta$-blockers), and preventing platelet aggregation (acetylsalicylic acid). With inadequate control of angina following these initial measures, efforts are then directed towards anatomical reconfiguration of stenotic coronary arteries. Depending on various factors such as patients' coronary anatomy and health status, either PTCA or CABG will most often be the optimal treatment. Due to inadequate anatomy, usually involving small coronary arteries with poor distal vascular beds, a significant number of patients will not be amenable to either PTCA or CABG. [2] These patients and their medical management form a complex therapeutic problem for treating physicians. Despite optimal pharmaceutical management, they are unable to participate in daily activities of normal living, are unable to work, and frequently require multiple doctor visits and hospital re-admissions. Thus any potential aide to this often frustrating medical problem has been met with both excitement and skepticism in the medical community. TMR is such an aide, with current clinical trials suggesting that severity of angina is improved after laser treatment [3-5] While clearly encouraging, TMR has yet to be globally accepted because of various controversies. Firstly, the mechanism of action has been widely debated. Arguments for channel patency have been fervent and inconsistent. Formation of new blood vessels, angiogenesis, has been suggested but remains to be proven. Denervation of the myocardium with loss of afferent pain fibers may also be a potential mechanism. Secondly, other benefits such as improved exercise capacity, survival, or cardiac function may not occur with TMR. And thirdly, the procedure itself is associated with albeit small, but significant mortality.

Nevertheless, with studies suggesting a clinical improvement in pain sensation, scientific explanations have lagged behind industry-driven trials for any potential applicability of laser therapy. As the next segment will discuss in greater detail, one of the 
most likely explanations for TMR's apparent clinical success may center around its angiogenesis-inducing capabilities. The main objective of this work is to attempt to provide mechanistic insights into TMR's effect at the microscopic level. Ability to understand the mechanism of TMR could lead to further research involving issues such as the power of laser pulsations, type of laser, role of mechanical injury in promoting angiogenesis, timecourse of expected benefits/response, potential combination with angiogenic therapy.

A review of the literature is thus presented, in order to provide a link between the historical perspective of myocardial revascularization and the need for alternative surgical treatments such as TMR.

\section{LITERATURE REVIEW}

\section{A. Myocardial Revascularization}

The earliest attempts at reducing pain from angina pectoris focused on superior cervical sympathetic ganglion resection. [6] This was followed by operations aimed at decreasing cardiac metabolism, such as thyroidectomy $[7,8]$ and electrical stimulation of the carotid sinus. [9] These early operations, however, would yield to procedures aimed at increasing myocardial blood flow.

The augmentation of coronary circulation, aimed at satisfying myocardial metabolic demands, eventually supplanted most attempts at physiologic alterations. Claude Beck was the first to report on increased vasculature to the epicardium from pericardial adhesions. [10] He subsequently reported on the use of pectoralis major muscle flaps to ischemic portions of the heart in order to promote blood flow to that area of myocardium $[11,12]$ While other investigators proceeded to omental graft procedures [13] and ligation of the great cardiac vein [14] with limited success, Beck went on to popularize "cardiopericardiopexy" using various irritating substances such as powdered beef bone, asbestos, and dilute trichloracetic acid to promote the enhancement of adhesions. By 
combining this with narrowing of the coronary sinus, known as the Beck I operation, over 90\% of patients were improved and 50\% were relieved of angina. [15] The Beck II operation, one of the first to divert mediastinal blood flow to the heart by inserting an arterial graft between the thoracic aorta and coronary sinus, $[16,17]$ never gained popularity due to its complexity.

Beck's extensive work from 1932-54 was followed by studies showing improvement in $68 \%$ of patients who underwent ligation of both intemal mammary arteries. [18] However, these promising results were quickly dismissed by other investigators who found no protective effect in ligating an internal mammary artery with acute coronary artery occlusion. [19] Other failed attempts such as pulmonary artery-to-left atrial shunt [20] and creating an ascending aortic coarctation, while increasing knowledge about coronary circulation, would give way to various methods of direct myocardial revascularization.

Success in other vascular areas of the body, using venous grafts, plastic, or homografts were to be translated to coronary antery reconstruction. Alexis Carrel had first reported the interposition of a segment of carotid artery between the thoracic aorta and coronary artery in a canine model. [21] Gordon Murray, of Toronto, rejuvenated the topic in 1953 by reporting success with the interposition of venous or arterial grafts to replace stenotic arterial segments. [22] By 1967, the experience of anastomosing the internal mammary artery to a coronary artery was reported in six patients. [23]

With ongoing developments in cardiopulmonary bypass to arrest the heart, reports of coronary endarterectomy became available. $[24,25]$ However, mortality remained high, $[26,27]$ coupled with the introduction of selective coronary arteriography by Sones in 1959, [28] leading to the first human reports of aortocoronary bypass using saphenous vein by Sabiston in 1962. [29] Within a few years, Effler and Favalero successfully demonstrated the clinical applications and reliability of coronary bypass. [30-32] With similar reports of success using the internal mammary graft, [33] direct myocardial revascularization would become the standard of care for surgical correction of coronary 
atherosclerotic disease. It would supplant all other available treatment modalities, including Arthur Vineberg's myocardial implantation of the internal mammary artery.

\section{B. Myocardial Anatomy and Role of Sinusoids}

In 1933, Wearn injected non-physiologic substances into post-mortem hearts at supernormal pressures. [34] By examining 15 autopsied hearts, he concluded that there was convincing evidence of a fine myocardial network communicating directly between the coronary arteries and the ventricular cavities. This led to the belief that there was a rich sinusoidal network connecting capillaries and the ventricular lumen, which participated in oxygenation of the myocardium. While it is known that in early fetal life the mammalian heart resembles the reptilian heart with its extensive myocardial sinusoidal network, [35] most of these sinusoids will undergo "compaction" as the heart develops, becoming nonexistent in all but exceptional circumstances [36] In nearly all cases, the coronary vascular system will develop concurrently and control the blood supply to the heart. Nevertheless, Weam's sinusoidal theory served as the basis for a new technique by Arthur Vineberg. In the "Vineberg Operation," the internal mammary artery (IMA) was implanted through a tunnel made in the myocardium, [37,38] allowing the open-ended intercostal branches to bleed into the myocardium. Despite moderate clinical success [38-42] and angiographic evidence of IMA patency, [43] the reliability of coronary artery bypass, in its blossoming stage, would render this operation obsolete. Doubt on this operation's theoretical aim was cast in 1973, when Chiu demonstrated this rich sinusoidal network to likely be interstitial space. [44] Many other operations would be tried to promote circulation from the ventricles, but with very little acceptance. U-shaped arterial grafts through the ventricular cavity back into the myocardial walls were tried. [45] A t-shaped prosthesis was inserted into the subendocardial layer of the ventricular wall. [46] However, this ideology would also give rise to another new approach to myocardial revascularization, namely the first reports of transmyocardial acupuncture by $\mathbf{P}$. K. Sen. 


\section{Development of Transmyocardial Punctures}

Sen's introduction in 1965 of the "snake heart" operation would be the first clinical description of this procedure, while forming the basis for future treatments with laser TMR. In two reports, $[47,48]$ Sen speculated that by using 19-gauge cannulae to puncture as many as $\mathbf{2 0}$ holes per square centimeter, the heart could be perfused during systole through direct channels from the ventricle to the sponge-like free wall. His results showed that TMR was effective in reducing infarct size and mortality in dogs subjected to acute left anterior descending artery ligation. Sen also demonstrated histological evidence of patent transmural channels several weeks after their creation (Figure 2). While similar findings were reported by Khazei, [49] others could not duplicate his results, showing the channels to be histologically closed. Work by Pifarre suggested that even during diastole, intramural pressure was greater than left ventricular cavity pressure. [50] This allowed him to conclude that blood flow from the ventricle to the myocardium was a "physiological impossibility." These findings, combined with growing confidence in coronary artery bypass surgery, would cause any enthusiasm over myocardial acupuncture to subside. Even Walter's study in 1971, which showed an uptake of radicactive ${ }^{86} \mathrm{Rb}$-chloride in an area treated by acupuncture, could not allow TMR to increase in popularity. [51]

By the late 1970's, clinicians began to identify a subset of patients with severe angina whose coronary anatomy, usually due to small coronary arteries, prevented them from being candidates for either coronary artery bypass surgery (CABG) or percutaneous transluminal coronary angioplasty (PTCA). This dilemma, coinciding with the development of high energy $\mathrm{CO}_{2}$ lasers, led Dr. Mahmood Mirhoseini to report on the first experiment using laser to perform TMR and to demonstrate patent and endothelialized channels. [52] By using a high-powered $\mathrm{CO}_{2}$ laser, as opposed to a needle, Mirhoseini believed that patent channels could be created. In this study, a 400 watt $\mathrm{CO}_{2}$ laser was used to decrease mortality in dogs subjected to left anterior descending artery ligation. The original laboratory work in dogs was quickly followed by other animal experiments 
showing patent and endothelialized channels [53] and several human reports [547] suggesting clinical improvement, angiographic visualization of patent vessels, and increased uptake of thallium isotopes in areas revascularized by laser. In 1988, the first study including 12 patients treated with TMR as an adjunct to bypass grafting was published, [56] reporting increased uptake of the thallium isotope in the areas revascularized by laser. These encouraging results would lead to a multitude of studies aimed at objectively assessing the clinical response to this surgery. Among the possible benefits, both patent channels [58] and improved quality of life [59] were observed. Others found that TMR with a 1000-watt $\mathrm{CO}_{2}$ laser caused recovery of contractility and a decrease in necrosis of an infarcted area at both 3 hours and 30 days [60]. In turn, larger phase I and II trials would suggest that patient receiving TMR experienced a drop in Canadian Cardiovascular Society (CCS) angina class from 3.7 at baseline to 1.7 at 6 months, with treadmill times increasing from 4.6 to 9.9 minutes. [61] Positron emission tomography (PET) scans documented a 21 percent increase in the subendocardial to subepicardial perfusion ratio, which indicated a reversal in the direction of myocardial perfusion in favor of endocardial dominance. Another study [62] again suggested a significant improvement in CCS angina class from 3.7 to 1.0 in 20 patients after having undergone TMR 13-26 months previously. Twelve-month follow-up from the Texas Heart Institute [63] showed a continued 20-percent increase in the resting mean subendocardial/subendocardial perfusion ratio of laser-treated regions, continued gain in treadmill exercise time from 4.3 minutes at baseline to 10.0 minutes, and continued reduction in angina class from 3.7 at the time of TMR to 1.8 at 12 months. A multi-center trial in patients unsuitable for direct revascularization again showed a decrease in the severity of angina which persisted at least 12 months post TMR. [64] In 15 patients having undergone $\mathrm{CO}_{2}$ laser TMR, dobutamine stress echocardiography revealed significant improvements in wall motion score index (WMSI) at peak stress in lased segments at 3 months, lasting to 6 months post TMR. [65] With other studies suggesting clinical 
improvement $[66,67]$ with TMR, but without improvement in myocardial perfusion scans, proper phase III trial were initiated.

In a prospective, randomized, multi-center trial, 164 patients with CCS class IV angina were randomized to treatment with TMR with a Ho:YAG laser or maximal medical management. Inclusion criteria included coronary artery disease not amenable to conventional treatment, ejection fraction greater than $25 \%$, and reversible ischemia on nuclear scanning. Results showed that TMR-treated patients had a significantly greater improvement in angina symptoms and fewer hospital admissions for angina at 3 and 6 months post-treatment. [68] Other results presented in May of 1997 suggested that patients randomized to the TMR arm have less angina, along with improved quality of life and event-free survival. [69] One-year data involving this trial was submitted to the United States' Food and Drug Administration (FDA), where a hearing in early 1998 led to the approval of PLC Medical Systems' (Franklin, MA) $\mathrm{CO}_{2}$ laser as an accepted surgical modality for patients with end-stage angina.

Several other prospective randomized trials have recently been completed, in which TMR compares favorably to medical therapy for the treatment of unstable angina. Schofield reported on 188 patients randomly assigned to laser TMR or medical management alone. [70] Their findings revealed no significant difference in mean treadmill exercise time, mean 12-minute walk distance, or survival at 12 months (89\% for TMR versus $96 \%$ for medical therapy). However, the Canadian Cardiovascular Society score for angina had decreased by at least two classes in $25 \%$ of TMR and $4 \%$ of medicalmanagement patients at 12 months ( $p<0.001$ ). A second trial published in the Lancet reported on 182 patients from 16 centers in the United States with CCS scores of III (38\%) or IV (62\%), reversible ischemia, and incomplete response to other therapies. [71] Patients randomly assigned to TMR and continued medication had increased exercise tolerance $(p<0.0001)$, lower CCS scores $(p<0.001)$, and improved quality of life $(p<0.001)$ compared to patients treated with continued medication alone. The authors concluded that 
TMR provided clinical benefits in patients with no other therapeutic options. Two additional studies also revealed similar results. Allen reported on 275 patients from 18 centers, suffering from class IV angina and coronary disease that could not be treated with percutaneous or surgical revascularization. [72] Patients were randomized to either transmyocardial revascularization followed by continued medical therapy (132 patients) or medical therapy alone (143 patients). TMR patients had a much better improvement in angina ( $p<0.001$ ), a significantly higher rate of survival free of cardiac events $(p<0.001)$, a higher rate of freedom from treatment failure ( $p<0.001$ ), and a higher rate of freedom from cardiac-related re-hospitalization ( $p<0.001$ ). TMR patients also had better exercise tolerance and quality-of-life scores, but showed no difference in 1-year survival and myocardial perfusion, as assessed by thallium scanning. Frazier reported on 192 patients, also randomly assigned to receive TMR or continued medical treatment. [73] Angina again improved significantly in the TMR group ( $p<0.001$ ), as did quality of life and myocardial perfusion ( $\mathrm{p}=0.002$ ). After 1 year of follow-up, 2 percent of patients assigned to undergo transmyocardial revascularization were hospitalized because of unstable angina, as compared with 69 percent of patients assigned to medical treatment (p<0.001). Again, TMR was felt to improve cardiac perfusion and clinical status in patients with myocardial ischemia not amenable to coronary-artery bypass surgery or percutaneous transluminal coronary angioplasty.

\section{Mechanisms and Controversies in TMR}

While clinical reports about TMR are clearly encouraging, a certain amount of controversy exists regarding its mechanism. In its initial phases, development of this new therapy focused on producing patent myocardial channels, where blood could flow from the ventricular cavity, through the channel, and into ischemic myocardium. Original reports of this procedure included photos of patent channels, covered with endothelium $[47,48,52]$. However, this theory has suffered as mounting evidence suggests that 
regardless of the mechanism (needle, $\mathrm{CO}_{2}$ laser, $\mathrm{Ho}$ :Y AG laser), transmyocardial channels do not stay open $[50,77-85]$. In essence, most investigators now believe that although patients' symptoms improve, the transmural channels are most of ten blocked. Myocardial denervation is another mechanism postulated to explain the clinical improvement seen in these patients. Yet a third mechanism, perhaps the most important one, is the formation of new blood vessels, angiogenesis, secondary to the traumatic injury of TMR. Each of these theories are now explained in greater detail.

\section{(i) Patent channels}

In Sen's early studies, $[47,48]$ he compared the post-TMR human heart, and its sinusoids, to that of snakes, which derive most of their blood supply directly from the ventricular cavity. Vineberg used this sinusoidal theory as the reason behind his myocardial revascularization work, [38-41] where the internal mammary artery is implanted into ischemic myocardium. However, upon reviewing the literature, Tsang [74] found that although the notion of myocardial sinusoids had been perpetuated for over 60 years, the evidence for their presence did not truly exist. This observation thus contradicted the populist notion that TMR provides blood flow to a sinusoidal system in the myocardium. Despite this inadequate evidence of sinusoidal existence, many investigators have reported patent and endothelialized transmural channels, using a variety of techniques $[47,48$, $52,58,75,76]$.

To further complicate the picture, results of several studies have suggested that vessels created by either laser or needle do not stay open [50,77-86]. In fact, some of these reports, along with others, have demonstrated that TMR channels are obliterated at histological examination in a variety of models [78,80,87-90]. This controversy is summarized in Table 1 , indicating various conclusions of different studies.

Thus, there seems to be little doubt that TMR has a beneficial effect to the patient suffering from myocardial ischemia [70-73]. What is unclear, however, is the mechanism 
by which this occurs. With convincing data showing lack of channel patency, and with serious doubts having been cast on previously accepted myocardial microanatomy, one is left to decipher what role transmural channels may play in alleviating symptomatology.

\section{(ii) Denervation}

A second mechanism has been proposed to explain the clinical benefit seen with TMR. Denervation, the loss of neural stimulation, induced by mechanical trauma to the myocardium could explain the immediate improvement seen in some patients. The heart is supplied by autonomic nerve fibers of both sympathetic and parasympathetic origin. The sympathetic fibers travel from an apical to basal direction in the subepicardium, giving off deeper branches that course toward the endocardium. Cardiac afferents carrying pain sensation in $A \delta$ and $C$ fibers are thought to run alongside the sympathetic efferent fibers as they course centrally to convey the sensation of angina. [91]

Recent studies have addressed this possibility. Kwong studied the effects of Ho:YAG laser TMR on denervation in the canine heart [92]. In this paper, the hemodynamic response to topical bradykinin was compared in hearts treated with topical phenol versus Ho:YAG laser. The topical application of bradykinin to the myocardium is known to cause a decrease in mean arterial pressure via stimulation of cardiac afferent fibers. Topical phenol ablates this response to bradykinin through denervation. Also, sympathetic neural tissue was identified by using the stain tyrosine hydroxylase. Areas of myocardium treated with phenol and laser showed no response to topical bradykinin. In addition, these areas demonstrated a loss of staining to tyrosine hydroxylase, consistent with a significant decrease or absence of sympathetic neural tissue. Kwong and associates thus concluded that denervation was a possible contributing mechanism in the relief of angina seen in clinical studies.

In a follow-up study, the same group assessed the degree of denervation resulting from partial-thickness TMR [93]. As opposed to regular TMR, laser channels were created 
via an endomyocardial approach using the Ho: Y AG laser, from endocardium to myocardium. This approach was found to attenuate, but not abolish, the response to topical bradykinin and the amount of staining for tyrosine hydroxylase.

Perhaps the most definitive study on cardiac denervation was carried out by Hirsch et al. [94] Changes in ventricular dynamics and cardiac afferent neuronal activity were monitored before and after creating 20 channels in the ventral left ventricular free wall with a Holmium:YAG laser. The responses to three different modes of stimuli were recorded, namely 1) the application of veratridine or bradykinin to the epicardial sensory neurites of intrinsic cardiac afferent neurons, 2) sympathetic or parasympathetic efferent neuronal activation either electrically ( $4 \mathrm{~V}, 10 \mathrm{~Hz}, 5 \mathrm{~ms}$ ) or chemically (nicotine, $5 \mu \mathrm{g} / \mathrm{kg}$ i.v.), and 3) direct cardiomyocyte $\beta$-adrenoceptor stimulation (isoproterenol, $5 \mu \mathrm{g}$, i.v.). Results showed that sensory neurites of right atrial afferent neurons responded similarly to chemical stimulation before and after TMR, local ventricular contractile responses to activation of sympathetic or parasympathetic efferent neurons was not reduced, and cardiomyocyte augmentor responses elicited by exogenous $\beta$-adrenergic receptor challenge were not affected. By all three methods, they concluded that TMR does not affect afferent or efferent axonal function in the treated left ventricle.

While denervation may have a role in reducing angina symptoms, the current experimental work does not support this theory as the sole responsible mechanism. In search of a better explanation, another mechanism, namely that of angiogenesis, has been postulated.

\section{(iii) Angiogenic growth factors}

Since neither channel patency or denervation can satisfactorily explain the clinical improvements seen with TMR, a third mechanism has surfaced. It has been proposed that the injury caused by TMR could lead to neovascularization in the areas of laser or needle 
injury $[83,95]$. This theory has support in the body's natural response to injury; the mechanisms of wound healing. In non-cardiac tissues, tissue injury leads to a well known cascade of coagulation, inflammation, and granulation tissue. During the inflammatory phase, there is an influx of macrophages, neutrophils, and platelets. These cells, along with the endothelium in the area of injury, release a number of inflammatory mediators, including cytokines, which produce local changes in the circulation and act as chemoattractants. This is followed by fibroblast proliferation and wound remodeling [96].

If one views the laser as an injury-causing mechanism, it is conceivable that TMR could incite a wound healing response. The tissue injury caused by laser TMR was recently described. [97] The interaction of laser photons with intact myocardial cells causes a total ablation of this tissue. Damage can occur in two ways. Organic bonds can be directly broken, as with the ultraviolet laser, or through high energy levels generated from the vaporization of water from the infrared laser's strong absorption by water. Either mechanism can ultimately lead to damage of myocardial tissue surrounding the area of injury (transmural channel). In addition to this mechanical injury, the laser heat can generate steam or gaseous breakdown products of tissue proteins, which in turn can cause thermal injury from the escape of gas into the surrounding tissues. Regardless, these reactions induce a wound healing response which has yet to be quantitated.

\section{E. Modulation of Angiogenesis}

\section{(i) Role in wound healing}

Neovascularization is an essential part of the inflammatory process if wound healing is to occur. Induction of angiogenesis is mediated by the release of several cytokines from neutrophils, macrophages, and endothelial cells amongst others [96,98]. At least eight cytokines have recently been identified as angiogenic polypeptides in vivo. $[99,100]$. Although it is not entirely clear how these effector cells are activated to release 
angiogenic molecules, hypoxia has been found to induce expression or secretion of these molecules. Among them, vascular endothelial growth factor (VEGF), fibroblast growth factor (FGF), and transforming growth factor- $\beta$ (TGF- $\beta$ ) have particularly been associated with various angiogenesis models [98]. Using this information, many studies have now shown promising effects of angiogenic substances in accelerating impaired wound healing [98]. However, these studies have focused on tissues such as dermis and duodenum (chronic ulcers). The applicability to other tissues is only now beginning to be understood.

\section{(ii) Role in ischemic myocardium}

The role of angiogenic growth factors in promoting neovascularization in myocardial tissue has recently become a popular topic [98]. Myocardial ischemia necessitates an improvement of the vascular supply. This is often achieved by emerging collaterals which protect the myocardium from ischemic damage $[98,101]$. The presence of collateral vessels in patients with ischemic heart disease provides myocardial protection following an acute infarction. In other words, "coronary collateral vessels protect myocardial tissues from ischemia during coronary artery stenosis." [101] This protection is manifested as a lower incidence of $Q$ waves and pump failure in patients suffering myocardial infarcts when collaterals are visible angiographically [102-105]. Experimental studies also reveal that complete coronary occlusion, if induced gradually, may result in no myocardial infarction at all $[106,107]$.

Such observations provide striking evidence for the importance of coronary collateral perfusion in the prevention or limitation of infarct size. One can only imagine the potential benefits of creating a significant anastomotic vascular supply before coronary blood flow is acutely stopped. Since the transmural extent of a human myocardial infarct is determined at least in part by the amount of collateral blood flow to this region [108], promotion of collateral formation could prove to be excellent prophylaxis against the effects 
of acute coronary artery occlusion. In order to do this, investigators have studied the effects of various angiogenic growth factors on the development of collateral vessels. So far the results have been encouraging. Basic fibroblast growth factor (bFGF) enhanced maximal collateral blood flow in dogs with myocardial ischemia secondary to single-vessel coronary occlusion [109]. Intra-coronary injection of bFGF improved cardiac function and reduced infarct size from $19.9 \%$ to $5.5 \%$ (ratio of infarct/LV weight) when administered after creation of an acute myocardial infarct [110]. Treatment with bFGF also increased the number of arterioles and capillaries in the infarcted area. Intra-pericardial injection of bFGF decreased infarct size and increased the vascular number in the infarcted area, mostly in the subepicardial area [111]. Yet another study using affigel blue beads containing bFGF showed higher microvessel counts in the experimental group $(66.7 \pm 4.9$ per field vs $49.6 \pm 5.2, p=0.05$ ), as compared with that in the control group [112]. When administered peri-adventitially, bFGF again resulted in an improvement of coronary flow and reduction in infarct size in the compromised territory as well as in prevention of pacinginduced hemodynamic deterioration [113]. Although not studied as extensively, other growth factors, notably VEGF, TGFß, and platelet derived growth factor (PDGF) have also displayed angiogenic properties [98]. VEGF is expressed by various cells present during myocardial injury. These cells include macrophages, fibroblasts, smooth muscle cells, and endothelial cells. VEGF receptors are exclusively located on the endothelial cells, thereby making it a potent mitogen [114]. TGFß induces angiogenesis indirectly via effects on other cells. It potentiates bFGF- and VEGF-induced angiogenesis, leading to proliferation of endothelial cells and formation of capillary-like tubes of bovine microvascular endothelial cells [98]. To briefly summarize the association between growth factors and the heart, angiogenesis results from the expression of many growth factors, prominent ones being bFGF, VEGF, and TGFB. Addition of these growth factors to ischemic myocardium provides a protective effect, thereby reducing myocardial damage. 
However, an association between transmyocardial revascularization and growth factor expression has yet to be demonstrated. This association provides the main objective for this thesis.

\section{RATIONALE FOR THESIS}

A significant amount of data suggests that providing ischemic myocardium with angiogenic growth factors (e.g. bFGF), via several different routes, leads to neovascularization, and by extension, to myocardial protection in the event of acute myocardial ischemia. Myocardial tissue injury, by mechanical or hypoxic mechanism, leads to an attempt at wound healing, which in some tissues is manifested by the overexpression of angiogenic growth factors. Another group of studies suggests that TMR increases the blood supply to ischemic myocardium to such an extent that it may relieve angina and reduce infarct size. However, there is ongoing debate as to the mechanism involved with TMR. While some suggest that angiogenesis may be involved in this mechanism, no studies have attempted to adequately validate this claim. Several questions are thus left unanswered by the current state of knowledge. Does TMR cause an overexpression of angiogenic growth factors? If so, which growth factors are expressed? Can TMR produce an extensive collateral circulation by promoting wound healingassociated angiogenesis? At what time is the neovascularization response optimal following injury? In myocardium, can mechanisms other than hypoxia, such as mechanical trauma, lead to endogenous production of growth factors? Based on these questions and relevant literature, the following hypothesis is proposed. To support or refute this statement is the main objective of this thesis. 


\section{STUDY HYPOTHESIS}

Transmyocardial revascularization causes a mechanical injury to ischemic myocardium, initiating a wound healing response, with a main component of this process being the formation of new blood vessels (angiogenesis).

\section{STUDY DESIGN}

Based on the working hypothesis, a study was designed to determine if TMR is associated with either angiogenesis and/or growth factor expression of TGFß, bFGF, or VEGF. An ischemic rat myocardial model was designed using needle-made channels as the injury-causing stimulus for inflammation and possible angiogenesis. Reasons for choosing these particular variables are as follows:

(1) Creation of channels. Needles were chosen rather than either $\mathrm{Ho}: \mathrm{YAG}$ or $\mathrm{CO}_{2}$ laser for several reasons. Most importantly, the stated hypothesis proposes that any mechanical injury, not only that caused by laser energy, will lead to a wound healing and angiogenic response. Needles are much less costly than expensive laser equipment. The creation of controlled transmural channels in a rat heart is not technically feasible with the current lasers available. The energy displayed would create an overabundance of myocardial damage, rendering the heart non-viable. In addition, a report by Whittaker suggests that needle channels are superior to laser channels in preserving rat myocardium subjected to left coronary ligation.[115]

(2) Animal. Rats were chosen over other animal species for several reasons. The human heart is composed of two main coronary arteries with limited collateralization in heal thy subjects. The rat heart is similar to the human heart in this aspect, containing only 
two main coronary arteries and few collaterals. In contrast, canine hearts are heavily collateralized. While the porcine heart is anatomically adequate, its use is associated with extremely higher financial costs. Apart from their anatomical advantage, rats are small, rendering the surgical treatments much easier and quicker. For histological analysis, crosssectional views of rat hearts can be produced on one slide only, allowing for a more complete analysis of appropriate locations and treatment areas.

(3) Ischemia Rat hearts were rendered ischemic by ligating a coronary artery before treatment with TMR was administered. The rationale for this was to resemble the clinical situation in humans, where only patients with evidence of myocardial ischemia may be candidates for TMR. While the model for this study is in actuality an infarct model, it is nonetheless better than solely examining healthy myocardium. A true ischemia model is not possible in rodent hearts because of their minuscule size. Present-day ischemia models utilize an ameroid constrictor (Research Instruments, Corvallis, Oregon) which is placed around a coronary artery. With time, the ameroid swells, slowly compressing the artery in a concentric manner. Since rodent arteries are so small, such devices are not available.

\section{A. Statement of Sigmificance}

In order to justify meaningful research, there must be an element of significance. For this thesis, the significant aspects include:

1) TMR is presently undergoing clinical trials. However, the mechanisms involved are being debated. Those that believe channel patency is critical, emphasize the use of laser to produce the channels. Such lasers come at high costs, and should channel patency play a minimal part to the effects of TMR, more economical methods of TMR may be introduced.

2) Preliminary clinical trials have suggested that improved perfusion occurs a few weeks after the procedure. By chronologically outlining the tissue changes with TMR, we 
will be better able to identify the optimal timing of the benefits and identify candidates for TMR.

3) If tissue factors are identified which contribute to the benefit of TMR, we will be better able to refine and optimize the methods of TMR.

\section{MATERIAL AND METHODS}

\section{A. Animals}

Male Lewis rats weighing between $250-300 \mathrm{~g}$ were used for all experiments (Charles River Laboratories, Wilmington, MA). Animals were divided into two groups. Group I (control, $n=25$ ) underwent ligation of the left coronary artery only. Group II (experimental, $n=28$ ) underwent ligation of the left coronary artery along with TMR at the same operation. Each group had 20 survivors, which were sacrificed in subgroups of five at intervals of 1, 2, 4, and 8 weeks. All animal work was performed in accordance with institutional guidelines, which is in compliance with the "Guide for the Care and Use of Laboratory Animals," published by the National Institutes of Health.

\section{B. Surgery}

In both groups, anesthesia was induced and maintained with enflurane $2-4 \%$ at 1-2 L/min. Rats were intubated with a 14-gauge I.V. catheter and ventilated at a tidal volume of $2.5 \mathrm{cc}$ and a respiratory rate of $90 /$ minute. The left chest was shaved and prepped with $1 \%$ hibitane. A left thoracotomy was created in the 4 th intercostal space and the lung retracted posteriorly. After incising the pericardium, the left coronary artery (LCA) was identified in its course between the left atrium and pulmonary artery. In both groups, the LCA was ligated with one suture of 5-0 silk. In preliminary work, ischemia was confirmed by both tachycardia and the acute presence of large $S$ waves on the electrocardiogram. In group I, the chest was then closed in three layers of 4-0 Vicryl, while in group II, transmyocardial punctures were performed with a 25-gauge needle. Six transmural channels were created in the distribution of the LCA, with caution to avoid 
puncturing any large coronary veins. Hemostasis was achieved with slight pressure in all cases. Chest closure was identical to the control group. Both groups were allowed to recover, and postoperative pain was controlled with subcutaneous injections of buprinorphine (0.1-0.5 mg/kg) for 24-48 hours. Each group was then divided into four subgroups, which were sacrificed at periods of $1,2,4$, and 8 weeks postoperatively.

\section{Harvest}

After the pre-determined period of one to eight weeks, animals were again anesthetized, intubated, and ventilated as before. A midline incision was made from the sternal notch to the mid-abdomen. The stemum was removed, followed by isolation and cannulation of the aortic root with a 20-gauge I.V. cannula. Beating hearts were arrested and fixed in diastole with $10 \mathrm{mls}$ of $4 \%$ paraformaldehyde, then stored at $4^{\circ} \mathrm{C}$. After 24 hours, the hearts were washed and stored in PBS solution containing 15\% sucrose, again at $4^{\circ} \mathrm{C}$.

\section{Immunohistochemistry}

Cryostat sections of tissue were immunostained with antisera to TGFB, bFGF, and VEGF ligands (Santa Cruz Biotechnology, Inc.) with a modification of the avidin biotinperoxidase method [116]. Hearts were cut into 3-5 mm cross-sectional slices, and slides mounted with $10 \mu \mathrm{m}$ sections. Tissue sections were made permeable with Triton $\mathrm{X}-100$, incubated in hydrogen peroxide to block endogenous peroxidase activity, and incubated first with normal serum for 30 minutes and then with the primary antibody for 16 hours at $4^{\circ} \mathrm{C}$. Sections were then incubated with biotinylated IgG and stained with an immunoperoxidase technique according to the manufacturer's instructions (Vectastain ABC Elite Kit, Vector Laboratories, Burlingame, Calif.). Antiserum to factor VIII (the endothelial-cell marker von Willebrand factor) was also used. Extra sections were also stained with hematoxylin and eosin. 


\section{E. Image Analysis}

Angiogenesis was assessed in a blinded fashion by counting the number of vessels per high powered field (HPF, x250). Vessels were defined as round structures with a central lumen which is lined by cells staining positively to factor VIII. Sampling was performed by the accepted method of "systematic sampling with a random start," [117] and was performed in the infarcted area, which was defined by the following criteria:

-thinning of ventricular wall

-loss of normal myocyte appearance and homogeneity

-presence of inflammatory cells and fibroblasts

-presence of granulation tissue

For TGFß expression, quantification was performed with digital morphometric image analysis, again in a blinded fashion. By using the same sampling method as mentioned for factor VIII, the outlines of TGFB positively stained cells at HPF (400x) were highlighted in both the infarcted and non-infarcted myocardium, using ten sampling sites per infarct zone. For VEGF and bFGF, expression was measured in the infarcted zone only. Results were quantitated in $\mathrm{mm}^{2} / \mathrm{mm}^{2}$ of myocardial tissue.

\section{F. Statistics}

Data were analyzed with parametric (student's t-test) and nonparametric (MannWhitney) methods, using InStat ${ }^{\mathrm{TM}}$ statistical software. A p-value less than 0.05 was considered significant.

\section{RESULTS}

\section{A. Mortality}

Table 2 shows the mortality associated with both the control group (Group I, LCA occlusion) and the experimental group (Group II, LCA occlusion + TMR). Most deaths were caused by ventricular arrhythmias or asystole following LCA occlusion. In 3 hearts 
of group I and in $\mathbf{2}$ hearts of group II, an area of infarct could not be found by histological criteria.

\section{B. Angiogenesis.}

Figures 3 and 4 represents an example of a high-powered field with several small vessels, elliptical areas surrounded by Factor VIII staining. The number of capillaries per HPF (x250) was significantly greater in the infarcted area of the group II when compared to group $I$, with a mean of $5.65 \pm 5.2$ vs. $4.06 \pm 2.8$ vessels/HPF respectively $(p<0.001)$. In both groups, the number of vessels was greatest at 1 week and decreased progressively until the 8th week (Figure 5). When examined by subgroup, a significantly higher vascular density was found in group II compared to group I at 1 week $(9.12 \pm 6.3$ vs. 5.56 \pm 3.5 vessels/HPF, $p<0.0001)$ and 4 weeks $(4.84 \pm 5.0$ vs. $3.14 \pm 2.4$ vessels/HPF, $\mathrm{p}=0.003)$, but not at 2 weeks $(4.17 \pm 3.5$ vs. $4.26 \pm 1.9$ vessels/HPF, $p=0.25)$ and 8 weeks $(3.41 \pm 2.6$ vs. $2.55 \pm 1.8$ vessels $/ H P F, p=0.058)$.

\section{TGF- $\beta$}

In the infarcted myocardium, computerized morphometric image analysis revealed the area of TGF- $\beta$ staining to be significantly increased in the TMR group compared to the control group $\left(0.207 \pm 0.23\right.$ vs. $0.141 \pm 0.18 \mathrm{~mm}^{2} / \mathrm{mm}^{2}$ of myocardial tissue, $\left.p=0.049\right)$. In both groups, several cells stained positively for TGF $\beta$, including endothelial cells, myocytes, fibroblasts, and macrophages. In general, small cells such as fibroblasts and macrophages produced a very intense staining pattern, while myocytes produced a larger but less intense pattern. TGF $\beta$ expression was highest at 1 week and progressively declined until the 8th week (Figure 6 ) in both groups. When analyzed by subgroup, group II was found to have significantly more TGFß than group I at 2 weeks $(0.282$ 0.33 vs. $0.102 \pm 0.11 \mathrm{~mm}^{2} / \mathrm{mm}^{2}$ of myocardium, $\left.\mathrm{p}=0.041\right)$ and 8 weeks $(0.102 \pm 0.09$ vs. $0.060 \pm 0.07 \mathrm{~mm}^{2} / \mathrm{mm}^{2}$ of myocardium, $\mathrm{p}=0.041$ ), but results at 1 and 4 weeks were 
not significantly different $\left(0.300 \pm 0.26 \mathrm{vs} .0 .216 \pm 0.20 \mathrm{~mm}^{2} / \mathrm{mm}^{2}\right.$ of myocardial tissue, $p=0.25$; and $0.162 \pm 0.23$ vs. $0.153 \pm 0.17 \mathrm{~mm}^{2} / \mathrm{mm}^{2}$ of myocardial tissue, $p=0.65$ ).

Similar to the vascular density results, TGFß expression peaked at one week and decreased over the ensuing 8 weeks. Figure 7 demonstrates an example of TGF $\beta$ staining in the infarcted myocardial zone.

In the non-infarcted myocardium, which served as a control for TGFB expression, staining was markedly more diffuse than in the infarcted area. This appeared to be related to an increased presence of normal, viable myocytes which stain diffusely. No significant difference in the amount of TGF $\beta$ expression could be demonstrated between the TMR and control groups $\left(0.675 \pm 0.72\right.$ vs. $0.600 \pm 0.692 \mathrm{~mm}^{2} / \mathrm{mm}^{2}$ of myocardium, $\left.\mathrm{p}=0.63\right)$. In the four subgroups (Figure 8), TGFB expression remained stable throughout weeks 1 to 8 in both groups I and II $\left(0.585 \pm 0.15\right.$ vs. $0.836 \pm 0.84 \mathrm{~mm}^{2} / \mathrm{mm}^{2}$ of myocardium at I week, $\mathrm{p}=0.76 ; 0.660 \pm 1.05$ vs. $0.627 \pm 0.093 \mathrm{~mm}^{2} / \mathrm{mm}^{2}$ of myocardium at 2 weeks, $\mathrm{p}=0.40 ; 0.630 \bullet 0.23$ vs. $0.603 \oplus 0.13 \mathrm{~mm}^{2} / \mathrm{mm}^{2}$ of myocardium at 4 weeks, $\mathrm{p}=0.23$; and $0.504 \pm 0.17$ vs. $0.591 \oplus 0.14 \mathrm{~mm}^{2} / \mathrm{mm}^{2}$ of myocardium at 8 weeks, $\mathrm{p}=0.14$ ), as shown in Figure 8.

\section{D. bFGF}

Many cells were stained for bFGF, including myocytes, macrophages, and fibroblasts. The area of positive staining to bFGF in the infarct zone was significantly greater in group II compared to group I $\left(0.125 \pm 0.11 \mathrm{vs} .0 .099 \pm 0.072 \mathrm{~mm}^{2} / \mathrm{mm}^{2}\right.$ of myocardium, $\mathrm{p}=0.027$ ). In the four subgroups, bFGF expression was significantly greater in group II at 4 and 8 weeks $\left(0.101 \pm 0.046 \mathrm{vs}\right.$. $0.080 \pm 0.056 \mathrm{~mm}^{2} / \mathrm{mm}^{2}$ of myocardium, $p=0.021$; and $0.105 \pm 0.042$ vs. $0.049 \pm 0.053 \mathrm{~mm}^{2} / \mathrm{mm}^{2}$ of myocardium, $p<0.0001$ ) but not at 1 and 2 weeks $\left(0.169 \pm 0.16\right.$ vs. $0.141 \pm 0.082 \mathrm{~mm}^{2} / \mathrm{mm}^{2}$ of myocardium, $p=0.69$; and $0.117 \pm 0.10$ vs. $0.123 \pm 0.086 \mathrm{~mm}^{2} / \mathrm{mm}^{2}$ of myocardium, $\mathrm{p}=0.29$ ) respectively, as 
shown in Figure 9. As with vascular density and TGFB results, the maximal expression of bFGF occurred at 1 week and declined over the next 8 weeks.

E. VEGF

As with bFGF, VEGF staining was noted mostly in myocytes, macrophages, and fibroblasts. No differences in VEGF expression were found between groups I and II ( $0.091 \pm 0.12$ vs. $0.095 \bullet 0.13 \mathrm{~mm}^{2} / \mathrm{mm}^{2}$ of myocardium, $\mathrm{p}=0.69$ ) in the infarct zone. When comparing the subgroups of group II to group I, no significant difference in VEGF expression was found at $1,2,4$, and 8 weeks respectively $(0.181 \pm 0.21$ vs. $0.132 \pm 0.12$ $\mathrm{mm}^{2} / \mathrm{mm}^{2}$ of myocardium, $\mathrm{p}=0.86 ; 0.088 \pm 0.049$ vs. $0.104 \pm 0.15 \mathrm{~mm}^{2} / \mathrm{mm}^{2}$ of myocardium, $\mathrm{p}=0.48 ; 0.050 \pm 0.054$ vs. $0.053 \pm 0.049 \mathrm{~mm}^{2} / \mathrm{mm}^{2}$ of myocardium, $\mathrm{p}=0.97$; and $0.043 \pm 0.042$ vs. $0.041 \bullet 0.049 \mathrm{~mm}^{2} / \mathrm{mm}^{2}$ of myocardium, $\mathrm{p}=0.97$ ), as shown in Figure 10. However, as with the other growth factors, maximal expression of VEGF was observed at one week before declining over the ensuing 8 weeks.

\section{viII. DISCUSSION}

Transmyocardial revascularization is currently being investigated as a surgical option for patients suffering from intractable angina. In fact, at least one laser company, PLC Systems, has received Federal Drug Administration (FDA) approval for use of its technology. Early phase I and II trials have shown that TMR can drastically reduce the severity of angina, as graded by the Canadian Cardiovascular Society (CCS) score [61$64,66,67]$. Some reports have demonstrated an improvement in subendocardial versus subepicardial resting perfusion in the laser treated areas at 12 months [61-63], with another suggesting significant improvements in wall motion score index (WMSI) at 3 months, lasting to 6 months post TMR. [65] Results of phase III clinical trials have shown promising results [68-73]. In one multi-center study, event free survival, angina class, and quality of life all appear to be improved after TMR compared to continued medical 
management in patients with symptomatic, end-stage coronary artery disease [69]. Other well-designed prospective randomized trials consistently demonstrate a reduction in the severity of angina [70-73] and a better quality of life [71-73]. Although no study has yet to demonstrate a clear survival benefit from TMR, there is increasingly strong evidence to suggest that it is an effective treatment for end-stage symptomatic myocardial ischemia.

Despite clinically promising results, the mechanisms by which TMR reduces angina remain unknown. Following original controversies surrounding channel patency, an increasing number of investigators currently believe that channels become obliterated, and are therefore unable to directly provide blood to the ischemic myocardium. While there are many reports claiming that channels are patent $[47,52,56,58,60,115,118]$, most recent reports indicate the opposite $[50,77-86]$. The theory that myocardial denervation is responsible for symptomatic relief has also been recently refuted [94]. The most interesting hypothesis to explain the effect of TMR states that this procedure may promote an angiogenic response, which would provide collateral blood flow to an otherwise underperfused area of the heart [95]. Our analysis of angiogenesis data by comparing vascular density yielded two main findings which appear to support this hypothesis. Firstly, in all group II animals combined, the mean vascular density was significantly greater than that of the control group. Secondly, vascular density appeared to have maximized at one week before decreasing over the next 8 weeks. These results suggest that some component of the TMR procedure leads to angiogenesis, perhaps by the wellknown mechanism of injury and wound healing response. If TMR is viewed as a form of mechanical trauma which creates a controlled injury to myocardium, certain comparisons can be made to other human tissues. In skin and muscle, for example, hypoxic or mechanical trauma will initiate a cascade of coagulation, inflammation, and granulation tissue formation. This is followed by fibroblast proliferation and wound remodeling [96]. Altogether, this inflammatory process is capable of inducing the formation of new vessels by secreting soluble angiogenic molecules [98]. In our model, both groups underwent 
ligation of the left coronary artery, creating severe hypoxia to the myocardium, in itself a potent inducer of angiogenesis. However, addition of the mechanical injury of TMR in group II is likely to have caused the observed additional increase in vascular density. Our second observation, that of decreasing vascular density over time, may be explained by the known process of wound-healing. With time, the inflammatory process may lead to increased scar tissue formation via fibroblast proliferation and collagen deposition. Dense scar tissue may allow fewer vessels to survive. Another explanation may be a deficiency in our model, whereby the creation of an infarct failed to provide immature blood vessels with enough proteins and nutrients to stimulate their growth. Perhaps this observation of decreased vascular density over time would be different in a model of chronic ischemia, similar to that of the clinical TMR patients, which can provide a continued stimulus for angiogenic growth factor release.

These growth factors are a group of hormone-like polypeptides which have been shown to play a central role in different phases of wound healing. The repair of injury begins with the release of peptide growth factors from both inflammatory cells and injured cells as soon as tissue damage occurs [119]. They include basic fibroblast growth factor (bFGF), vasoendothelial growth factor (VEGF), transforming growth factor- $\beta$ (TGFB), and platelet derived growth factor (PDGF). Our second major goal in this study was to examine the expression of angiogenic growth factors in our model of TMR. Of the three growth factors studied, the overall concentrations of TGFB and bFGF over 8 weeks were increased in the TMR group over the control group, although this was not observed with VEGF. For all three growth factors, however, maximal expression occurred at 1 week and decreased over the ensuing 8 weeks, as it had for vascular density. In order to understand this pattern of growth factor expression, it is helpful to identify which cells are capable of producing them. TGFß, for example, when implicated in wound repair mechanisms, functions partly through its role as a potent chemo-attractant for monocytes and fibroblasts 
$[120,121]$. In other words, TGF $\beta$ induces angiogenesis indirectly via other cells. These cells can then secrete angiogenic molecules, such as VEGF and bFGF, which act directly on endothelial cells. In addition to monocytes and fibroblasts, many other cells such as cardiocytes, macrophages, smooth muscle cells, and endothelial cells amongst others, are capable of synthesizing VEGF and bFGF [98]. Unlike TGF $\beta$, they are direct acting angiogenic molecules since they elicit angiogenesis and remodeling of the vasculature via their own receptors on endothelial cells [122]. In our experiment, the creation of a myocardial infarct led to a marked inflammatory and wound-remodeling response, mainly via its hypoxic effect. In the TMR group, increased levels of TGF $\beta$ and bFGF suggest an increase in their progenitor cells, as a possible explanation. Given a concomitant increase in vascular density, the increased presence of endothelial cells may itself be responsible for elevated levels of TGFB and bFGF. However, the injury to myocardium caused by TMR may conceivably cause a higher fibroblastic response, which in itself may increase growth factor expression. This issue needs further evaluation. A clear explanation is also lacking for the discrepancy between VEGF and bFGF results. Since both are mostly secreted by the same cell types, one would have expected similar results. However, our model appears to favor bFGF synthesis, a molecule which has been shown to be induced rapidly and in time to yield beneficial effects in myocardial infarcts [1110,113].

The observed decrease in vascular density and growth factor expression with time, in our model may be explained by considering angiogenesis as occurring in two phases [122]. The first phase of activation includes cell migration and extracellular matrix invasion, along with endothelial cell proliferation. This phase will introduce many cells which are known to stain for factor VIII (endothelial cells) and to produce TGFb, bFGF, and VEGF (macrophages, fibroblasts). The second phase, that of resolution, encompasses termination of angiogenesis and vessel maturation, via steps such as inhibition of 
endothelial cell proliferation and cessation of cell migration. Our observations of declining vascular density may thus be a natural process of angiogenesis, from the activation to resolution phases.

Another possibility for the decrease in vascular density may be due to the infarct component of our model. In the early phases of a myocardial infaret, a dense inflammation will occur, but myocardial cells may still remain present and viable for some time. As they continue to be deprived of their blood supply, these myocytes eventually die, yielding way to fibroblastic proliferation and granulation tissue formation. Since myocytes are known to produce growth factors, an observation confirmed in our study, their decrease over time could be a cause for decreased growth factor expression from 1 to 8 weeks. Whittaker, in using a model similar to ours, described less infarct damage when rat hearts were pretreated with TMR (both needle- and laser-made channels) [115]. Perhaps this increase in myocardial viability is a causative factor for group II's elevated growth factors levels, at least in the early phase.

Finally, we also observed similar TGF $\beta$ levels in the non-infarcted (control area) myocardium of groups I and II. This finding is of great importance in validating our model. Since no intervention was performed in these areas, one would have expected to find similar levels of growth factors. In addition, there would be no reason for growth factor expression to decrease with time, as it had in the infarcted area. Experimentally, these samples were measured from the right ventricle, an area which had neither been rendered ischemic nor injured with TMR. The expression of TGFB in these areas was limited almost exclusively to viable myocytes, since very few inflammatory cells were present. Since myocardial cells are much larger than fibroblasts, macrophages, or other inflammatory cells, a high powered field $(\times 400)$ in this area was overwhelmingly stained compared to the fields in a typically infarcted area. For example, in Group I at one week, TGFß expression in the infarcted zone was only $0.216 \mathrm{~mm}^{2} / \mathrm{mm}^{2}$ of myocardium 
compared to $0.585 \mathrm{~mm}^{2} / \mathrm{mm}^{2}$ of myocardium, a nearly 3-fold increase. Over a period of 8 weeks, the expression of TGF $\beta$ in this area did not decrease, a very different result from the one observed in the infarct zone.

\section{FUTURE STUDIES}

Future studies in this field should be focused on addressing the two main limitations of this study, namely (1) to observe the response to ischemia rather than infarction, and (2) to compare laser-versus needle-induced inflammation. A model of chronic ischemia was not technically feasible in the rat, an animal which was ideal for this experiment, given its lack of collateral blood supply, thereby ensuring a homogeneous infarct zone, and its relatively inexpensive cost, given the large number of animals required. In a future study, chronic ischemia may be induced in larger animals, the most appropriate likely being the pig. The pig's heart is quite similar to the human's in both size and lack of native collateral supply. An ischemic area may be induced by placing an ameroid constrictor on one of the coronary arteries. Over a period of 4-6 weeks, this device will expand, thereby slowly occluding the targeted artery. This has the advantage of creating a slowly ischemic zone, a situation which closely resembles the clinical human situation. The lack of an acute infarct also should allow these animals to survive, avoiding many of the cardiac arrhythmias, such as ventricular fibrillation and asystole, which were frequently associated with the animals in our model. The comparison of needle- versus laser-made channels will also be a very important aspect to examine. Large American industries have promoted this procedure based on the benefits of high-energy lasers to maintain patent channels. However, with overwhelming evidence suggesting that these channels become obstructed, their stance has shifted to a claim that lasers may induce "angiogenesis." This claim remains to be proven, but its implications are important. The 
cost of a typical high-powered $\mathrm{CO}_{2}$ laser is nearly $\$ 250,000$, compared to a few dollars for hypodermic needles. If needles are in fact capable of causing angiogenesis in ischemic myocardium, in addition to infarcted myocardium as shown in this study, then a comparison between lasers and needles must be made. The financial ramifications of such a study would be very important. If answers to these issues can be found, they may help to elucidate the underlying mechanism of clinical TMR.

\section{CONCLUSION}

In conclusion, this data appears to support the hypothesis that angiogenesis may play a role in TMR. With the long term patency of laser-created myocardial channels in clinical TMR increasingly in doubt, its mechanism may be similar to that observed in this model. If such a speculation can be confirmed, the efficacy of TMR using needle punctures, which is less expensive than using lasers, may deserve to be re-evaluated clinically. 


\section{LEGEND}

Table 1. Summary of most studies in which patency rate of TMR channels is reported. Table summarizes the author, methodology of revascularization, animal model, and author's statement on the patency of observed transmyocardial channels.

Table 2. Mortality and presence of infarct in rats subjected to ligation of left coronary artery with or without (groups I and II) TMR.

Figure 1. Schematic drawing provided by PLC Laser Inc. to demonstrate the methodology of transmyocardial revascularization (TMR) using a carbon dioxide $\left(\mathrm{CO}_{2}\right)$ laser.

Figure 2. Histological slide from P.K. Sen's original work on TMR, showing a channel lined by nucleated cells. This was shown as proof of channel patency, with the nucleated cells representing endothelial cells. [47]

Figure 3. Light photomicrograph of cross section of infarcted myocardium in TMR group. Multiple vacuolated circles surrounded by brownish-stained cells represent small vessels. Dense inflammatory tissue also present. (Factor VIII staining (brown) and hematoxylin and eosin (blue); $x$ 250.)

Figure 4. Similar to figure 3, this is a light photomicrograph of infarcted myocardium in TMR group. Multiple vacuolated circles surrounded by brownish-stained cells represent small vessels. (Factor VIII staining (brown) and hematoxylin and eosin (blue); $x 250$.) Figure 5. Bar graph showing the vascular density in number of vessels per highpowered field (x 250) in both the control (group I) and experimental groups (group II) at intervals of one to eight weeks, along with the overall comparison of both groups (all subgroups from 1 to 8 weeks combined).

Figure 6. Bar graph showing the area of staining to TGFB in $\mathrm{mm}^{2}$ of staining per $\mathrm{mm}^{2}$ of infarcted myocardium in both the control (group I) and experimental groups (group II) at intervals of one to eight weeks. 
Figure 7. Light photomicrograph of cross section of infarcted myocardium in the TMR group. Brown staining represents TGFB ligand expressed among a diffuse inflammatory background. (Hematoxylin and eosin; x250)

Figure 8. Bar graph showing the area of staining to TGFB in $\mathrm{mm}^{2}$ of staining per $\mathrm{mm}^{2}$ of non-infarcted myocardium in both the control (group I) and experimental groups (group II) at intervals of one to eight weeks. No statistical difference is present.

Figure 9. Bar graph showing the area of staining to bFGF in $\mathrm{mm}^{2}$ of staining per $\mathrm{mm}^{2}$ of infarcted myocardium in both the control (group I) and experimental groups (group II) at intervals of one to eight weeks.

Figure 10. Bar graph showing the area of staining to VEGF in $\mathrm{mm}^{2}$ of staining per $\mathrm{mm}^{2}$ of infarcted myocardium in both the control (group I) and experimental groups (group II) at intervals of one to eight weeks. No significant difference is present. 
Table 1. Pateney rate of TMR channels in various published studies.

\begin{tabular}{|c|c|c|c|}
\hline Author [reference] & Method of TMR & Model & $\begin{array}{l}\text { Channel } \\
\text { Patency }\end{array}$ \\
\hline $\begin{array}{l}\text { Sen, 1965]47] } \\
\text { Minoseini, 1981 [52] } \\
\text { Mirhoseini, } 1988 \text { [56] } \\
\text { Cooley, } 1994[58] \\
\text { Horvath, } 1995[60] \\
\text { Whittaker, } 1996 \text { [115] } \\
\text { Berving, } 1997 \text { [1 17] }\end{array}$ & $\begin{array}{l}\text { Needle } \\
\mathrm{CO}_{2} \text { laser } \\
\mathrm{CO}_{2} \text { laser } \\
\mathrm{CO}_{2} \text { laser } \\
\mathrm{CO}_{2} \text { laser } \\
\mathrm{Ho} \text { Y } \mathrm{AG} \text { laser + needle } \\
\mathrm{CO}_{2} \text { laser }\end{array}$ & $\begin{array}{l}\text { Dogs } \\
\text { Dogs } \\
\text { Humans } \\
\text { Humans } \\
\text { Sheep } \\
\text { Rats } \\
\text { Humans }\end{array}$ & $\begin{array}{l}\text { Yes } \\
\text { Yes } \\
\text { Yes } \\
\text { Yes } \\
\text { Yes } \\
\text { Yes } \\
\text { Yes }\end{array}$ \\
\hline $\begin{array}{l}\text { Pifarre, } 1969[50] \\
\text { Owen, } 1984[86] \\
\text { Hardy, } 1987[77] \\
\text { Feischer, } 1996[78] \\
\text { Kohmoto, } 1996[79] \\
\text { Kohmoto, } 1997[80] \\
\text { Malekan, } 1997[81] \\
\text { Fisher, } 1997[82] \\
\text { Yamamoto, } 1998[83] \\
\text { Walpoth, } 1998[84] \\
\text { Eckstein, } 1998[85]\end{array}$ & $\begin{array}{l}\mathrm{Needle} \\
\mathrm{CO}_{2} \text { laser } \\
\mathrm{Needle} \text { and } \mathrm{CO}_{2} \text { laser } \\
\mathrm{CO}_{2} \text { laser } \\
\mathrm{Ho}: \mathrm{YG} \text { laser } \\
\mathrm{CO}_{2} \text { laser } \\
\mathrm{CO}_{2} \text { laser and drill } \\
\mathrm{CO}_{2} \text { and } \mathrm{Ho} \text { Y } \mathrm{AG} \text { laser } \\
\mathrm{Ho}: \mathrm{YG} \text { laser } \\
\mathrm{CO} \text {, Ho: YAG, Erbium laser } \\
\mathrm{Ho}: \mathrm{YAG} \text { laser }\end{array}$ & $\begin{array}{l}\text { Dogs } \\
\text { Rats } \\
\text { Dogs } \\
\text { Pigs } \\
\text { Dogs } \\
\text { Dogs } \\
\text { Sheep } \\
\text { Dogs } \\
\text { Dogs } \\
\text { Pigs } \\
\text { Sheep }\end{array}$ & $\begin{array}{l}\text { No } \\
\text { No } \\
\text { No } \\
\text { No } \\
\text { No } \\
\text { No } \\
\text { No } \\
\text { No } \\
\text { No } \\
\text { No } \\
\text { No }\end{array}$ \\
\hline
\end{tabular}


Table 2. Postoperative Mortality and Infaret Presence.

\begin{tabular}{lccc}
\hline & $\begin{array}{c}\text { Control } \\
\text { Group }\end{array}$ & TMR & P-value \\
& Group & \\
\hline Rats entered in study, $\mathbf{n}$ & 25 & 28 & \\
Survivors to term, $\mathrm{n}$ & 20 & 20 & \\
Overall mortality, $\mathrm{n}(\%)$ & $5 / 25(20)$ & $8 / 28(29)$ & 0.54 \\
Histological infarct, $\mathrm{n}$ & 17 & 18 & 1.0 \\
\hline
\end{tabular}




\section{Figure 1.}

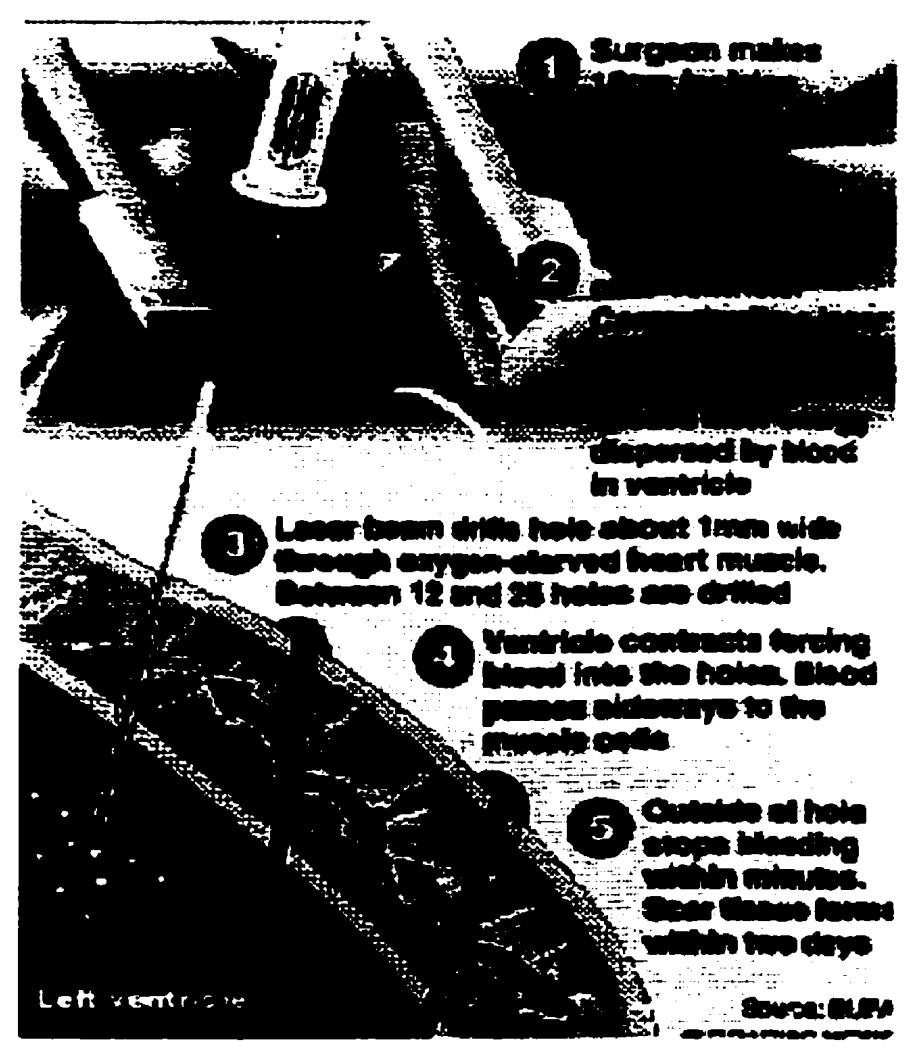




\section{Figure 2.}

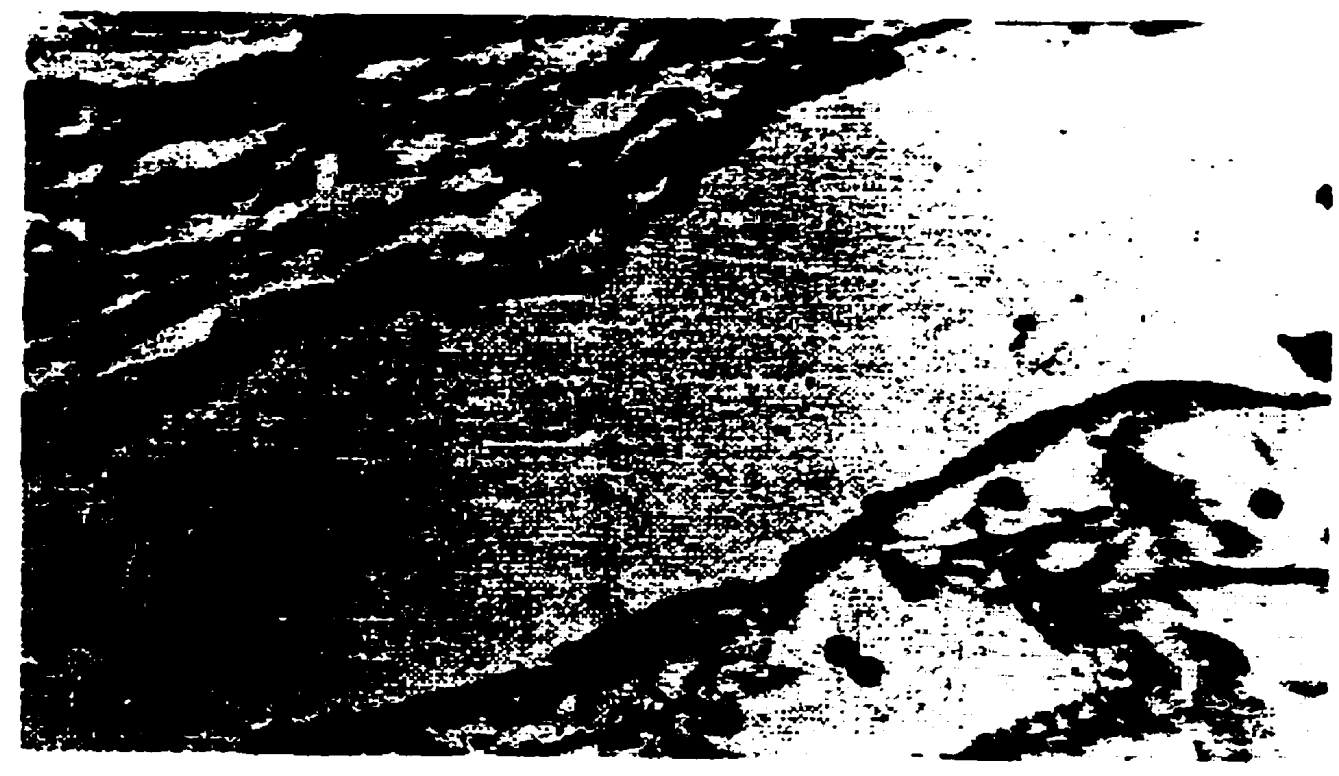




\section{Figure 3.}

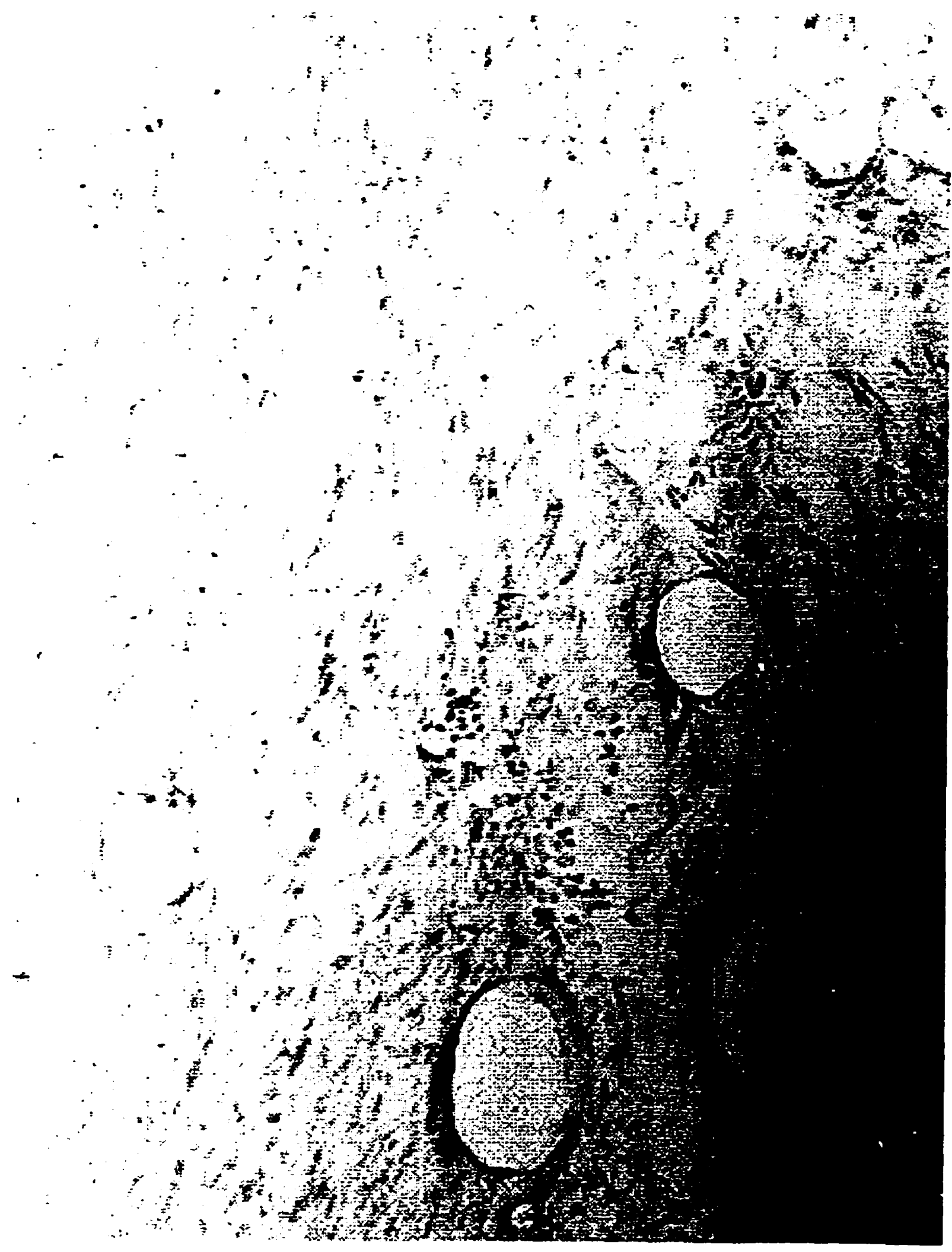




\section{Figure 4.}

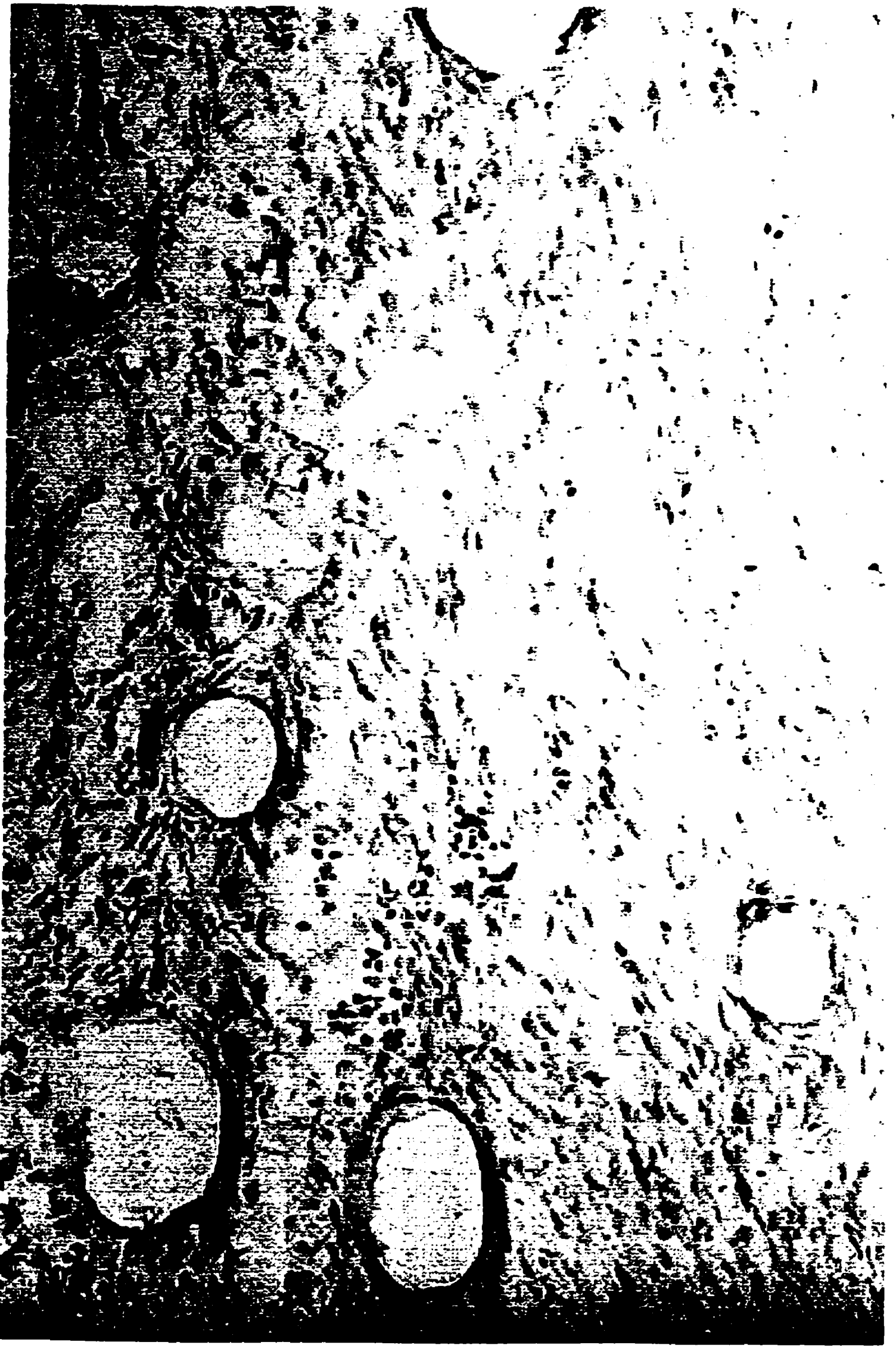


Figure 5.

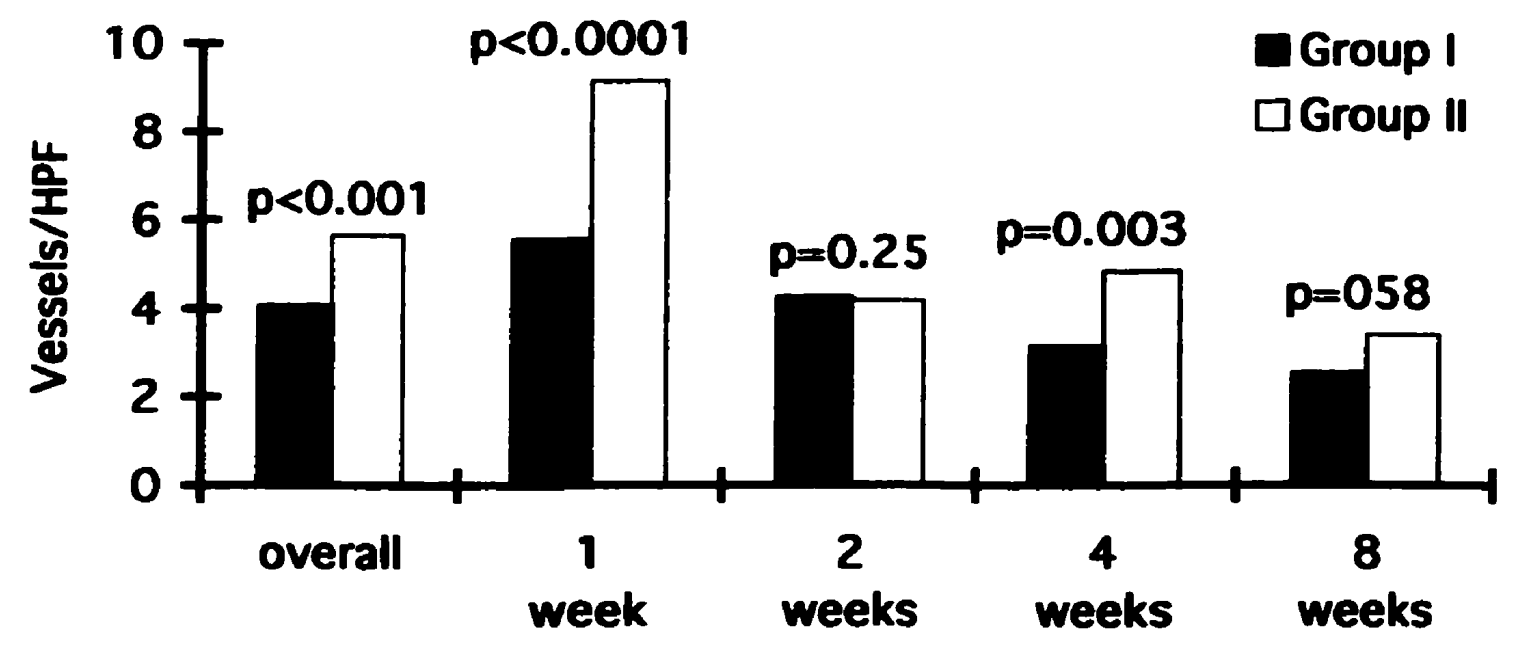


Figure 6.

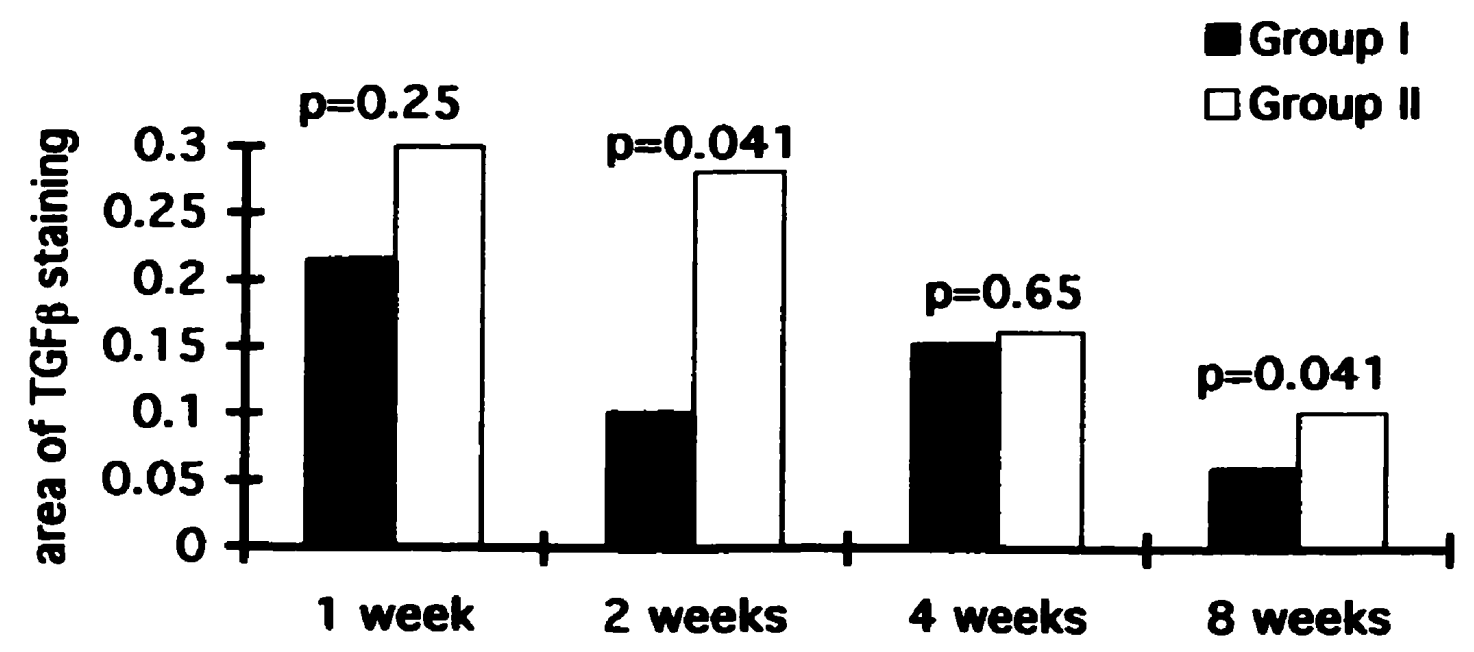




\section{Figure 7.}

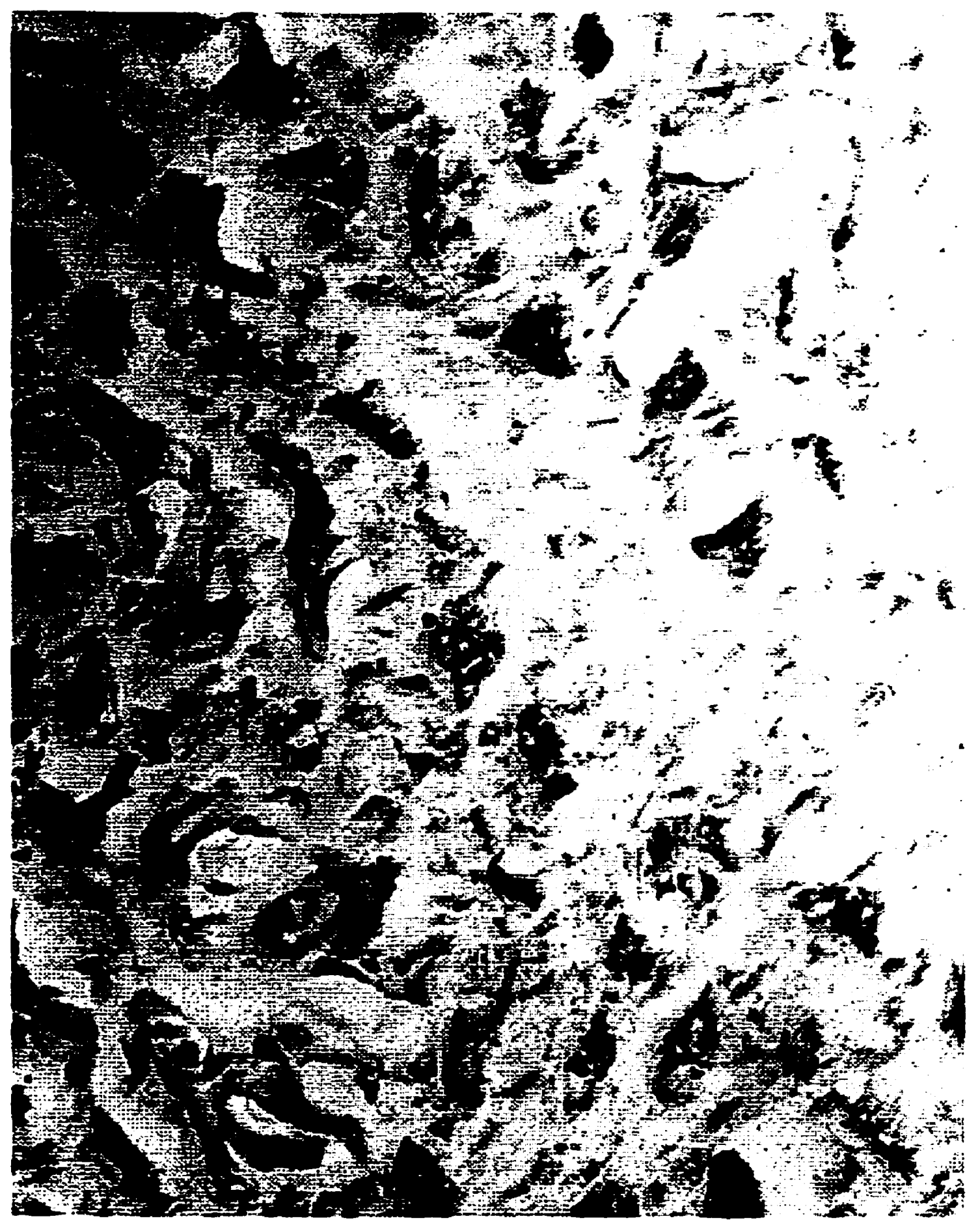


Figure 8.

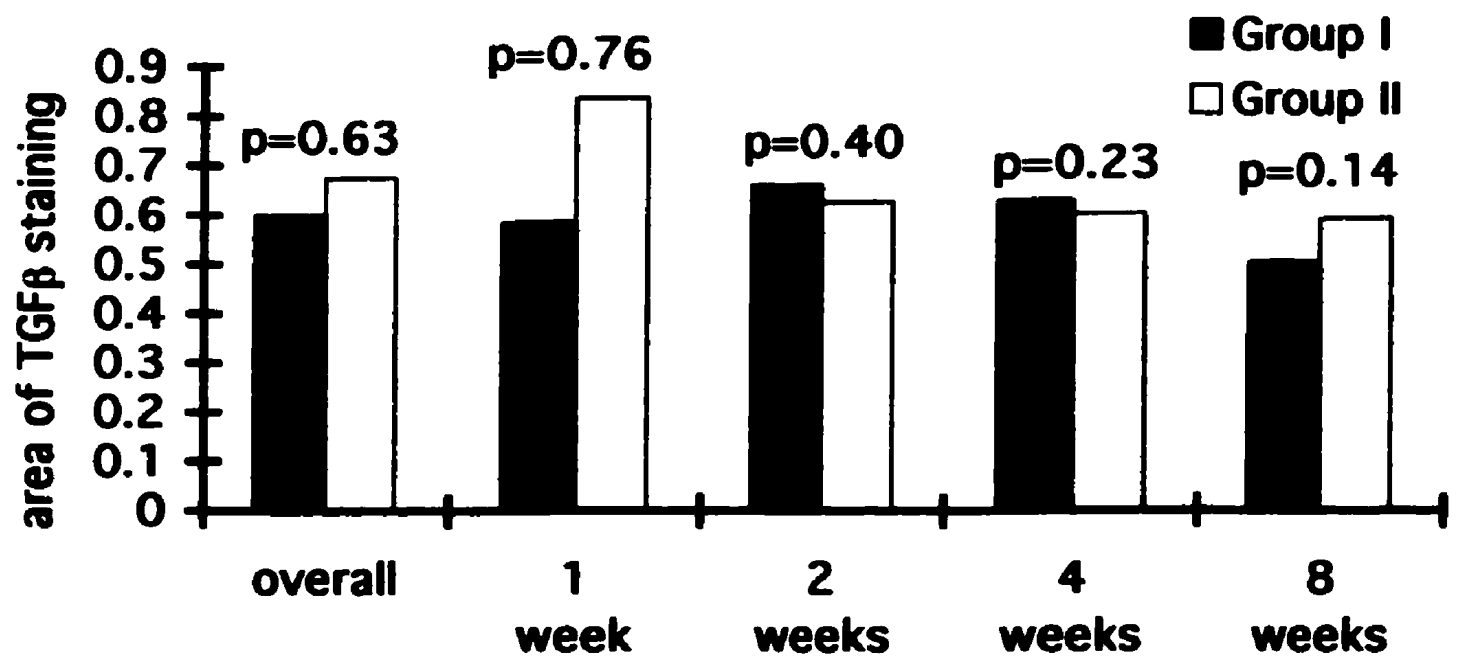


Figure 9.

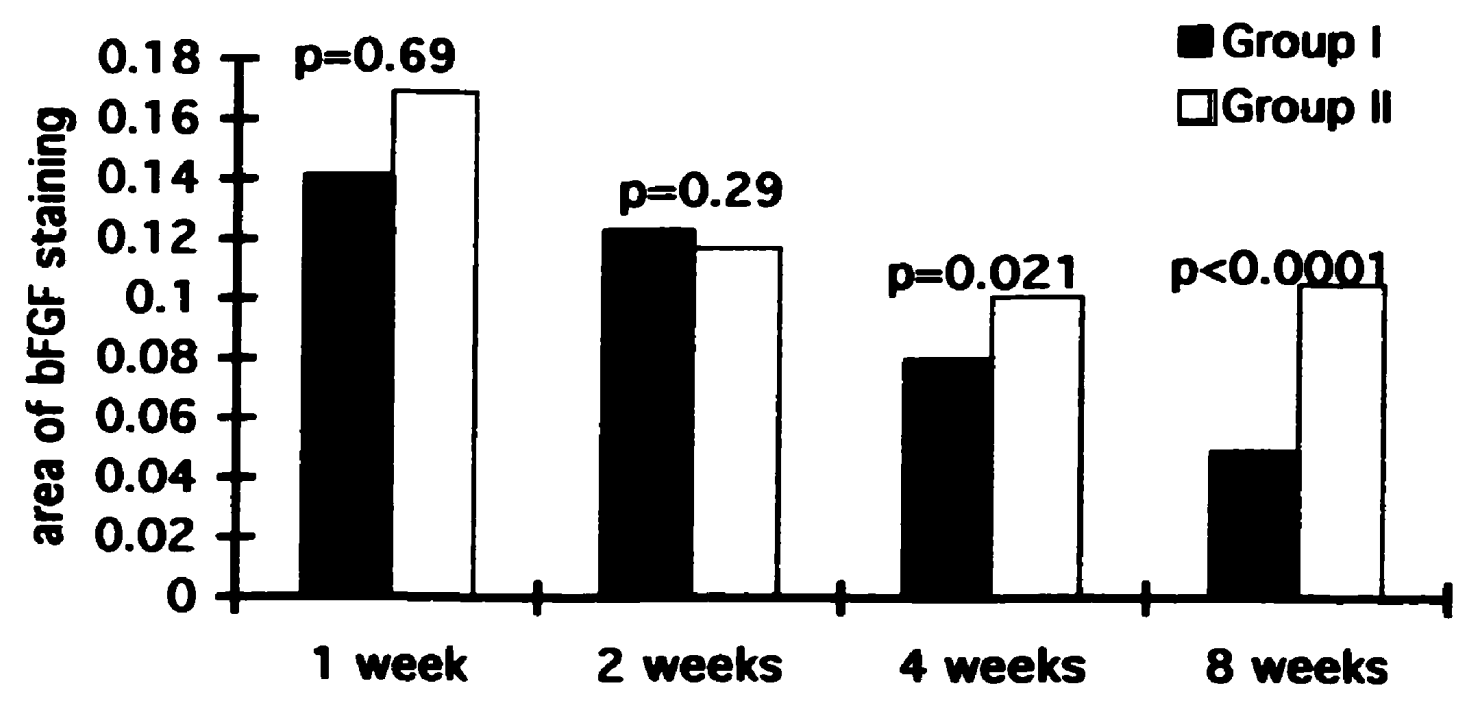


Figure 10.

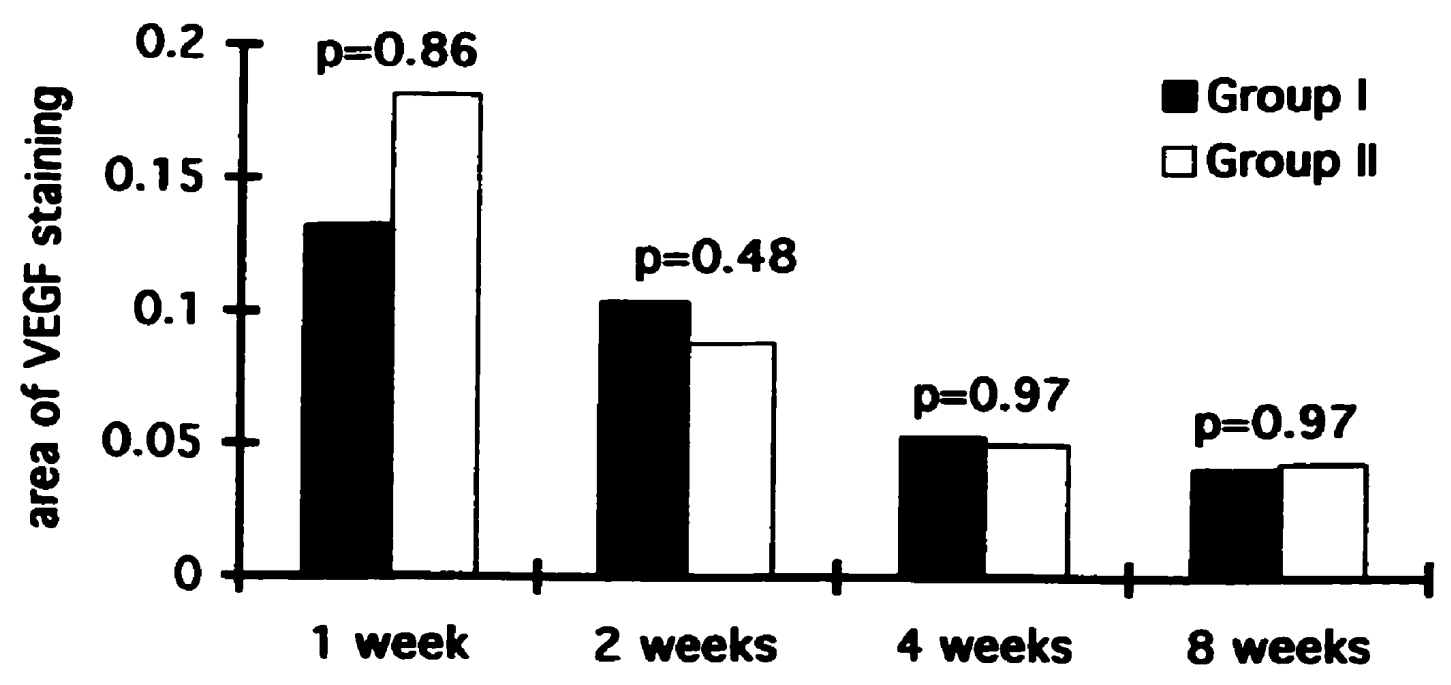




\section{REFERENCE LIST}

1. Braunwald, E. Heart Disease: A textbook of cardiovascular medicine. 1992, W. B. Saunders. p. 1302.

2. Mulcahy D. Knight C. Stables R. Fox K. Lasers, burns, cuts, tingles and pumps: a consideration of alternative treatments for intractable angina [editorial]. Br Heart $\mathbf{J}$ $1994 \mathrm{Dec} ; 72(6): 595$.

3. March RJ. Transmyocardial laser revascularisation with the $\mathrm{CO}_{2}$ laser: one year results of a randomized, controlled trial. Semin Thorac Cardiovasc Surg 1999;1 1:12-8.

4. Schofield PM, Sharples LD, Caine $\mathbf{N}$, et al. Transmyocardial laser revascularisation in patients with ref ractory angina: a randomized controlled trial. Lancet 1999;353:519. 24.

5. Allen K, Fudge T, Selinger $S$, et al. Prospective randomized multicenter trial of transmyocardial revascularization versus maximal medical management in patients with class IV angina. Circulation 1997;96(Suppl I):I-564.

6. Coffey WB, Brown PK. Surgical treatment of angina pectoris. Arch Int Med 1923:31:200-20.

7. Blumgart HL, Riseman JEF, Davis D, Berlin DD. Therapeutic effect of total ablation of normal thyroid on congestive heart failure and angina pectoris. III. Early results in various types of cardiovascular disease and coincident pathologic states without clinical or pathologic evidence of thyroid toxicity. Arch Int Med 1933;52:165-225.

8. Cutler EC, Levine SA. La douleur angineuse et son traitement chirurgical. Valeur des différentes méthodes, et plus particulièrement de la thyroidectomie totale. Presse Med 1934;46:937-40.

9. Braunwald E, Sonnenblick EH, Frommer PL, et al. Paired electric stimulation of the heart: physiologic observations and clinical implications. Adv Int Med 1967;13:61-96 
10. Beck CS, Tichy VL. Production of collateral circulation to heart; experimental study. Am Heart J 1935;10:849-73.

11. Beck CS. The development of a new blood supply to the heart by operation. Ann Surg 1935;102(5):801-13.

12. Beck CS. Further data on the establishment of a new blood supply to the heart by operation. J Thorac Surg 1936;23:665-70.

13. O'Shaughnessy L. An experimental method of providing a collateral circulation to the heart. Brit J Surg 1936;23:665-70.

14. Fauteux M, Palmer JH. Treatment of angina pectoris of atheromatous origin by ligation of the great cardiac vein. Can Med Assoc J 1941;45:295-8.

15. Beck CS, Leighninger DS. Operations for coronary artery disease. JAMA 1954;156:1226-33.

16. Beck CS, Leighninger DS. Scientific basis of the surgical treatment of coronary artery disease. JAMA 1955;159:126471.

17. Beck CS, Leighninger DS. Operations for coronary artery disease. JAMA 1954; 156:1226-33.

18. Glover RP, Davila JC, Kyle RH, Beard JC Jr, Trout RG, Kitchell JR. Ligation of the internal mammary arteries as a means of increasing blood supply to the myocardium. $J$ Thorac Surg 1957;34:661-78.

19. Vansant JH, Muller WH Jr. Experimental evaluation of intemal mammary artery ligation as a method of myocardial revascularization. Surgery 1959;45:840-7.

20. Day SB, Lillehei CW. Experimental basis for a new operation for coronary artery disease; a left atrial-pulmonary artery shunt to encourage the development of interarterial intercoronary anastamoses. Surgery 1959;45:487.

21. Edwards WS, Edwands PD. Alexis Carrel, Visionary Surgeon. 1974, Springfield III, Charles C. Thomas, pp 47. 
22. Murray G, Porcheron R, Hilario J, Roschau W. Anastomosis of a systemic artery to the coronary. Can Med Assoc J 1954;71:594-7.

23. Kilessov VI. Mammary artery-coronary artery anastomosis as method of treatment for angina pectoris. J Thorac Cardiovasc Surg 1967;54:535-44.

24. Bailey CP, May A, Lemmon WM. Survival after coronary endarterectomy in man. JAMA 1957;164:641-6.

25. Cannon JA, Longmire WP Jr, Kattus AA. Considerations of the rationale and technique of coronary endarterectomy for angina pectoris. Surgery 1959;46:197-21 1.

26. Absolon KB, Aust JB, Varco RL, Lellehei CW. Surgical treatment of occlusive coronary artery disease by endarterectomy or anastomotic replacement. Surg Gynec Obst 1956;103:180-5.

27. Effler DB, Groves LK, Sones FM Jr, Shirey EK. Endarterectomy in the treatment of coronary artery disease. J Thorac Cardiovasc Surg 1964;47:98-108.

28. Sones FM, Shirey EK. Cinecoronary arteriography. Mod Concepts Cardiovasc Dis 1962;31:735-8.

29. Sabiston DC Jr. Direct surgical management of congenital and acquired lesions of the coronary artery. Prog Cardiovase Dis 1963;6:299-316.

30. Favaloro RG. Saphenous vein autograft replacement of severe segmental coronary artery occlusion. Ann Thorac Surg 1968;5:334-9.

31. Favaloro RG. Saphenous vein graft in the surgical treatment of coronary artery disease. Operative technique. J Thorac Cardiovasc Surg 1969;58:178-85.

32. Favaloro RG, Effler DB, Groves LK, Sheldon WC, Riahi M. Direct myocardial revascularization with saphenous vein autograft. Clinical experience with 100 cases. Dis Chest 1969;56:279-83.

33. Spencer FC, Green GE, Tice DA, Glassman E Surgical therapy for coronary artery disease. Curr Probl Surg Sept, 1970. 
34. Wearn JT, Mettier SR, Klumpp TG, Zschiesche $L$. The nature of the vascular communications between the coronary arteries and the chambers of the hear. Am Heart J 1933;9:143-64.

35. Grant RT. Development of the cardiac coronary vessels in the rabbit. Heart $1926 ; 13: 261-71$.

36. Dusek J, Ostadal B, Duskova M. Postnatal persistence of spongy myocardium with embryonic blood supply. Arch Pathol 1975;99:312-7.

37. Vineberg AM, Miller D. Development of an anastomosis between the coronary vessels and a transplanted internal mammary artery. Can Med Assoc J 1947;56:609-14.

38. Vineberg A. Clinical and experimental studies in treatment of coronary artery insufficiency by internal mammary artery implant. J Int Coll Surg 1954;22:513-18.

39. Vineberg, AM. Coronary vascular anastomoses by internal mammary implantation. CMAJ 1958;78:871.

40. Vineberg AM, Deliyannis T, Pablo G. The Ivalon sponge procedure for myocardial revascularization. Surgery 1960;47:268.

41. Vineberg A, Munro DD, Cohen H, Buller W. Four years' clinical experience with internal mammary artery implantation in the treatment of human coronary artery insufficiency including additional experimental studies. J Thor Surg 1955;29:1.

42. Vineberg A, Buller $W$. Technical factors which favor mammary artery coronary anastomoses with report of 45 cases of human coronary artery disease thus treated. $J$ Thorac Cardiovasc Surg 1955:30:411-35.

43. Effler DB, Groves LK, Sones FM Jr, et al. Increased myocardial perfusion by internal mammary artery implantation: Vineberg's operation. Ann Surg 1963;158:526-34.

44. Chiu RCJ, Scott $\mathrm{HJ}$. The nature of early run-off in myocardial arterial implants. J Thorac Cardiovasc Surg 1973;65:768-77. 
45. Goldman A, Greenstone SM, Preuss FS, et al. Experimental methods for producing a collateral circulation to the heart directly from the ventricle. J Thoracic Surg 1956;31:364-74.

46. Massimo C, Boffi L. Myocardial revascularization by a new method of carrying blood directly from the left ventricular cavity into the coronary circulation. J Thorac Surg 1957:34:257-64.

47. Sen PK, Udwadia TE, Kinare SG, Parulkar GB, Parel MS. Transmyocardial acupuncture: A new approach to myocardial revascularization. J Thor Card Surg. 1965;50(2): 181-9.

48. Sen PK, Daulatram J, Kinare SG, Udwadia TE, Parulkar GB. Further studies in multiple transmyocardial acupuncture as a method of myocardial revascularization. Surg 1968;64(5):861-70.

49. Khazei AH, Kime WP, Papadopoulos C, Cowley RA. Myocardial canalization: a new method of revascularization. Ann Thorac Surg 1968;6(2):163-171.

50. Pifarre R. Jasuja ML Lynch RD. Neville WE Myocardial revascularization by transmyocardial acupuncture. A physiologic impossibility. J Thorac Cardiovasc Surg $1969 ; 58(3): 424-31$.

51. Walter $P$, Hundeshagen $H$, Borst $H G$. Treatment of acute myocardial infarction by transmural blood supply from the ventricular cavity. Eur Surg Res 1971;3:130-8.

52. Mirhoseini M, Cayton M. Revascularizaiion of the heart by laser. J Mictosurg $1981 ; 2: 871-75$.

53. Mirhoseini M, Muckerheide $M$, Cayton $M$. Transventricular revascularization by laser. Lasers Surg Med 1982;2:187-198.

54. Mirhoseini M, Fisher JC, Cayton M. Myocardial revascularization by laser. A clinical report. Lasers Surg Med 1983;3:241-5.

55. Mirhoseini M, Cayton M, Shelgikar S, Fisher JC. Clinical report: Laser myocardial revascularization. Lasers Surg Med 1986;6:459-61. 
56. Mihroseini M, Shelgikar S, Cayton $M$. New concepts in revascularization of the myocardium. Ann Thor Surg 1988;4:415-20.

57. Mirhoseini M, Shelgikar S, Cayton M. Clinical and histological evaluation of laser myocardial revascularization. J Clin Laser Med Surg 1990;(6):73-8.

58. Cooley DA, Frazier OH, Kadipasaoglu KA, Pehlivanoglu S, Shannon RL, Angellini P. Transmyocardial laser revascularization: anatomic evidence of long-term channel patency. Tex Heart Inst J 1994;21(3):220-4.

59. Raffa H. Transmyocardial laser revascularization: "The Mihoseini procedure." Saudi Heart J 1994;5:57 -62.

60. Horvath KA, Smith WJ, Laurence RG, Schoen FJ, Appleyard RF, Cohn LH. Recovery and viability of an acute myocardial infarct after transmyocardial laser revascularization. J Am Coll Card 1995;25:258-63.

61. Frazier OH, Cooley DA, Kadipasaoglu KA, Pehlivanoghhlu S, Lindenmeir M, Barasch E, Conger J, Wilanksky S, Moore WH. Myocardial revascularization with laser. Preliminary findings. Circ 1995;92:II58-II65.

62. Horvath KA, Mannting F, Cummings N, Shernan SK, Cohn LH. Transmyocardial laser revascularization: operative techniques and clinical results at two years. Journal of Thoracic \& Cardiovascular Surgery. 1996;11 1(5):1047-53.

63. Cooley DA, Frazier OH, Kadipasaoglu KA, et al. Transmyocardial laser revascularization: clinical experience with twelve-month follow-up. Journal of Thoracic \& Cardiovascular Surgery. 1996;11 (4):791-9.

64. Horvath KA, Cohn LH, Cooley DA, et al. Transmyocardial laser revascularization: results of a multicenter trial with transmyocardial laser revascularization used as a sole therapy for end-stage coronary artery disease. J Thorac Cardiovasc Surg 1997;113:645-54. 
65. Donovan $\mathrm{C}$, Landolfo $\mathrm{K}$, Lowe J, et al. Improvement in inducible ischemia during dobutamine stress echocardiography after transmyocardial laser revascularization in patients with refractory angina pectoris. J AM Coll Cardiol 1997;30:607-12.

66. Smith JA, Dunning JJ, Parry AJ, Large SR, Wallwork J. Transmyocardial laser revascularization. J Cardiac Surg 1995;10(5):569-72.

67. Raffa H, Memon F, Jabbad H, et al. Transmyocardial laser revascularization: Saudi Experience. Asian Cardiovasc Thorac Ann 1996;4:75-9.

68. Allen K, Fudge T, Selinger S, et al. Prospective randomized multicenter trial of transmyocardial revascularization versus maximal medical management in patients with class IV angina Circulation 1997;96 (Suppl I):I-564.

69. March RJ, Aranki S, Boyce S, et al. Improved event free survival following transmyocardial laser revascularization versus medical management in patients with unreconstructed coronary artery disease. Presented at the 7 th Annual Meeting of the American Association for Thoracic Surgery meeting, Washington, D.C., May 4-7, 1997.

70. Schofield PM, Sharples LD, Caine N, Burns S, Tait S, Wistow T, et al. Transmyocardial laser revascularisation in patients with refractory angina: a randomized controlled trial. Lancet 1999;353:519-24.

71. Burkhoff D, Schmidt S, Schulman SP, Myers J, Resar J, Becker LC, et al. Transmyocardial laser revascularisation compared with continued medical therapy for treatment of refractory angina pectoris: a prospective randomized trial. Lancet 1999:354:885-90.

72. Allen KB, Dowling RD, Fudge TL, Schoettle GP, Selinger SL, Gangahar DM, et al. Comparison of transmyocardial revascularization with medical therapy in patients with refractory angina. N Engl J Med 1999;341:1029-36. 
73. Frazier OH, March RJ, Horvath KA. Transmyocardial revascularization with a carbon dioxide laser in patients with end-stage coronary artery disease. $\mathbf{N}$ Engl J Med 1999;341-1021-8.

74. Tsang JCC, Chiu RCJ. The phantom of "myocardial sinusoids": A historical reappraisal. Ann Thorac Surg 1995;60:1831-5.

75. Mack CA, Magovem CJ, and Hahn RT. Channel patency and neovascularization after transmyocardial revascularization using an excimer laser: Results and comparisons to nonlased channels. Circ 1997;96(suppl II):II-65-II-69.

76. Kadipasaoglu KA, Pehlivanoglu S, Conger JL, et al. Long-and short-term effects of transmyocardial revascularization in acute myocardial ischemia. Surg Med 1997;20:614.

77. Hardy RI, Bove KE, James FW, Kaplan S, Goldman L. A histologic study of laserinduced transmyocardial channels. Las Surg Med 1987;6:563-73.

78. Fleischer K, Goldschmidt-Clermont PJ, Fonger JG, Hutchins GM, Hruban RH, Baumgartner WA. One-month histologic response of transmyocardial laser channels with molecular intervention. Ann Thorac Surg 1996;62:1051-8.

79. Kohmoto T, Fisher PE, Gu A, Zhu SM, Yano OJ, Spotnitz HM, Smith CR, Burkhoff D. Does blood flow through Holmium:YAG transmyocardial laser channels? Ann Thorac Surg 1996;61:861-8.

80. Kohmoto T, Fisher PE, Gu A, et al. Physiology, histology, and 2-week morphology of acute transmyocardial channels made with a $\mathrm{CO}_{2}$ laser. Ann Thorac Surg 1997;63:1275-83.

81. Malekan R, Reynolds C, Kelley S, et al. Angiogenesis in transmyocardial laser revascularization: a nonspecific response to injury. Circulation 1997;96 (Suppl I):I564. 
82. Fisher $\mathrm{P}$, Khomoto $T$, DeRosa $\mathrm{C}$, et al. Histologic analysis of transmyocardial channels: comparison of CO2 and Holmium:YAG lasers. Ann Thorac Surg $1997 ; 64: 466-72$.

83. Yamamoto N, Kohmoto T, Gu A, et al. Angiogenesis is enhanced in ischemic canine myocardium by transmyocardial laser revascularization. J Am Coll Cardiol 1998;31:1426-33.

84. Walpoth BH, Genyk I, Aeschbacher B, et al. Comparison of 3 different laser techniques for transmyocardial revascularization in the pig (Abstract). Presented at the 12th Annual Meeting of the European Association for Cardio-thoracic Surgery, Brussels, Belgium, 1998.

85. Eckstein F, Scheule A, Vogel U, et al. Transmyocardial laser revascularization with the Homium:YAG laser in the acute ischemic heart does neither improve acute myocardial perfusion nor does it prevent from myocardial infarction. An experimental study. Presented at the 12th Annual Meeting of the European Association for Cardiothoracic Surgery, Brussels, Belgium, 1998.

86. Owen ER, Canfield P, Bryant K, Hopwood PR. Observations on the effects of $\mathrm{CO}_{2}-$ laser on rat myocardium. Microsurgery 1984;5:140-3.

87. Zlotnick AY, Ahmad RM, Reul RM, et al. Neovascularization occurs at the site of closed laser channels after transmyocardial laser revascularization. Surg Forum 1996;47:286-7.

88. Krabatsch T, Schaper F, Leder C, Tulsner J, Thalmann U, Hetzer R. Histological findings after transmyocardial revascularization. J Card Surg 1996;11:326-31.

89. Burkhoff D, Fisher PE, Apfelbaum M, Kohmoto T, DeRosa CM, Smit CR. Histologic appearance of transmyocardial laser channels after 4 1/2 weeks. Ann Thorac Surg 1996;61:1532-5. 
90. Gassler N, Wintzer H-O, Stube H-M, Wullbrand A, Helmehen U. Transmyocardial laser revascularization: Histological features in human nonresponder myocardium. Circ 1997;95:371-75.

91. White JC. Cardiac pain: anatomic pathways and physiologic mechanisms. Circulation 1957;16:644-55.

92. Kwong K, Kanellopoulos G,Nickols J, et al. Transmyocardial laser treatment denervates canine myocardium. J Thorac Cardiovasc Surg 1997;114:883-90.

93. Kwong K, Kannelopoulos G, Schuessler R, et al. Endocardial laser treatment incompletely denervates canine myocardium. Circulation 1997;96(Suppl I):I-565.

94. Hirsch GM, Thompson GW, Arora R, Hirsch KJ, Sullivan J, Armour JA.

Transmyocardial laser revascularization does not affect neuronal innervation of the canine heart. Ann Thorac Surg 1999;68(2):460-8.

95. Zlotnick AY, Ahmad RM, Reul RM, et al. Neovascularization occurs at the site of closed laser channels after transmyocardial laser revascularization. Surg Forum $1996 ; 47: 286-7$.

96. Davidson JM. Wound repair. In: Gallin J, Goldstein IM, Snyderman R, editors. Inflammation: basic principles and clinical correlates. 2nd ed. New York: Raven Press, 1992:809-19.

97. Hartman RA, Whittaker P. The physics of transmyocardial laser revascularization. J Clin Laser Med Surg 1997;15:255-9.

98. Battegay EJ. Angiogenesis: mechanistic insights, neovascular diseases, and therapeutic prospects. J Mol Med 1995;73:333-46.

99. Folkman J, Klagsbrun M. Angiogenic factors. Science 1987;235:442-7.

100. Folkman J, Brem H. Angiogenesis and inflammation. In: Gallin J, Goldstein IM, Snyderman R, editors. Inflammation: basic principles and clinical correlates. 2nd ed. new York: Raven Press, 1992:821-39. 
101.Sabri MN, DiSciascio G, Cowly MJ, Alpert D, Vetrovec GW. Coronary collateral recruitment: functional significance and relation to rate of vessel closure. Am Heart J 1991;121:876-80.

102. Freedman SB, Dunn RF, Bernstein L, Morris J, Kelly DT. Influence of coronary collateral blood flow on the development of exertional ischemia and $Q$ wave infarction in patients with severe single-vessel disease. Circulation 1985;71:681-86.

103. Hamby RI, Aintablian A, Schewartz A. Reappraisal of the functional significance of the coronary collateral circulation. Am J Cardiol 1976;38:305-9.

104. Nohara R, Kambara H, Murakami T, Kadota K, Tamaki S, Kawai C. Collateral function in early acute myocardial infarction. Am J Cardiol 1983;52:955-9.

105. Williams DO, Amsterdam EA, Miller RR, Mason DT. Functional significance of coronary collateral vessels in patients with acute myocardial infarction: Relation to pump performance, cardiogenic shock and survival. Am J Cardiol 1976;37:345-51.

106. Gregg DE. The natural history of coronary collateral development. Circ Res $1974 ; 35: 335-44$.

107. Khouri EM, Gregg DE, McGranahan GM. Regression and reappearance of coronary collaterals. Am J Physiol 1971;220:655-61.

108. Lee JT, Ideker RE, Reimer KA Myocardial infarct size and location in relation to the coronary vascular bed at risk in man. Circ 1981;64:526-34.

109. Unger EF, Banai S, Shou M, Lazarous DF, Jaklitsch MT, Scheinowitz M, Correa R, Lingbeil C, Epstein SE. Basic fibroblast growth factor enhances myocardial collateral flow in a canine model. Am J Physiol 1994;266(Heart Circ Physiol 35):H1588H1595.

110. Yanagisawa-Miwa A, Uchida Y, Nakamura F, Tomaru T, Kido H, Kamijo T, Sugimoto T, Kaji K, Utsuyama M, Kurashima C, Ito H. Salvage of infarcted myocardium by angiogenic action of basic fibroblast growth factor. Science 1992;257:1401-3. 
111. Uchida Y, Yanagisawa-Miwa A, Nakamura F, Yamada K, Tomaru T, Kimura K, Morita T. Angiogenic therapy of acute myocardial infarction by intrapericardial injection of basic fibroblast growth factor and heparin sulfate: An experimental study. Am Heart J 1995;130:1182-8.

112. Battler A, Scheinowitz M, Bor A, Hasdai D, Vered Z, DiSegni E, Varda-Bloom N, Nass D, Engelberg S, Eldar M, Belkin M, Savion N. Intracoronary injection of basic fibroblast growth factor enhances angiogenesis in infarcted swine myocardium. J Am Coll Cardiol 1993;22:2001-6.

113. Harada K, Grossman W, Friedman M, Edelman ER, Prasad PV, Keighley CS, Manning WJ, Sellke FW, Simons M. Basic fibroblast growth factor improves myocardial function in chronically ischemic porcine hearts. J Clin Invest 1994;94:62330.

114. Folkman J, Shing Y. Angiogenesis. J Biol Chem 1992;267:10931-34.

115. Whittaker $P$, Rakusan $K$, Kloner RA. Transmural channels can protect ischemic tissue: Assessment of long-term myocardial response to laser- and needle-made channels. Circ 1996;93:143-52.

116. Hsu SM, Raine L, Fanger $H$. Use of avidin-biotin-peroxidase complex (ABC) in immunoperoxidase techniques: A comparison between ABC and unlabeled antibody (PA) procedures. J Histochem Cytochem 1981;29:577-80.

117. Weibel ER. Stereological methods, vol. 1, 1st ed. New York: Academic Press, $1979 ; 122$.

118. Berwing $K$, Bauer $E$, Strasser $R$, et al. Functional evidence of long-term channel patency after transmyocardial laser revascularization. Circulation 1997;96:I-564.

119. Cromack DT, Porras-Reyes B, Mustoe TA. Current concepts in wound healing: Growth factor and macrophage interaction. J Trauma 1990;30:S129-S133.

120. Wahl SM, Hunt DA. Transforming growth factor beta induces monocyte chemotaxis and growth factor production. Proc Natl Acad Sci USA $1987 ; 84: 5788$. 
121. Postlethwaite AI, Keski-Oja J. Stimulation of the chemotactic migration of human fibroblasts by transforming growth factor b. J Exp Med 1987;165:251-6.

122. Pepper MS, Mandriota SJ, Vassalli JD, et al. Angiogenesis-regulating cytokines: activities and interactions. Curr Top Micro Immun 1996;213:31-67. 